Central Washington University

ScholarWorks@CWU

All Faculty Scholarship for the College of the Sciences

2-12-2003

Energy-constrained open-system magmatic processes IV:

Geochemical, thermal and mass consequences of

energy-constrained recharge, assimilation and fractional crystallization (EC-RAFC)

Wendy A. Bohrson

Frank J. Spera

Follow this and additional works at: https://digitalcommons.cwu.edu/cotsfac

Part of the Geochemistry Commons, Geophysics and Seismology Commons, and the Volcanology Commons 


\title{
Energy-constrained open-system magmatic processes IV: Geochemical, thermal and mass consequences of energy- constrained recharge, assimilation and fractional crystallization (EC-RAFC)
}

\author{
Wendy A. Bohrson \\ Department of Geological Sciences, Central Washington University, Ellensburg, Washington, 98926, USA \\ (bohrson@geology.cwu.edu) \\ Frank J. Spera \\ Institute for Crustal Studies and Department of Geological Sciences, University of California, Santa Barbara, California, \\ 93106, USA
}

[1] A wealth of geochemical and petrological data provide evidence that the processes of fractional crystallization, assimilation, and magma recharge (replenishment) dominate the chemical signatures of many terrestrial igneous rocks. Previous work [Spera and Bohrson, 2001; Bohrson and Spera, 2001] has established the importance of integrating energy, species and mass conservation into simulations of complex magma chamber processes. An extended version of the energy-constrained formulation, EnergyConstrained Recharge, Assimilation, Fractional Crystallization (EC-RAFC), tracks mass and compositional variations of melt, cumulates, and enclaves in a magma body undergoing simultaneous recharge, assimilation, and fractional crystallization [Spera and Bohrson, 2002]. Because many EC-RAFC results are distinct from those predicted by extant RAFC formulations, the primary goal of this paper is to present a range of geochemical and mass relationships for selected cases that highlight issues relevant to modern petrology. Among the plethora of petrologic problems that have important, well-documented analogues in nature are the geochemical distinctions that arise when a magma body undergoes continuous versus episodic recharge, the connection between erupted magmas and associated cumulate bodies, the behavior of recharge-fractionation dominated systems (RFC), thermodynamic conditions that promote the formation of enclaves versus cumulates, and the conditions under which magma bodies may be described as chemically homogeneous. Investigation of the effects of continuous versus episodic recharge for mafic magma undergoing RAFC in the lower crust indicates that the resulting geochemical trends for melt and solids are sensitive to the intensity and composition of recharge, suggesting that EC-RAFC may be used as a tool to distinguish the nature of the recharge events. Compared to the record preserved in melts, the geochemical and mass characteristics of solids associated with particular RAFC events may record a more complete view of the physiochemical history of an open-system magma body. The capability of EC-RAFC to track melts and solids creates a genetic link that can be compared to natural analogues such as layered mafic intrusions and flood basalts, or mafic enclaves and their intermediate-composition volcanic or plutonic hosts. The ability to quantify chemical and volume characteristics of solids and melts also underscores the need for integrated field, petrologic and geochemical studies of igneous systems. While it appears that a number of volcanic events or systems may be characterized by continuous influx or eruption of magma ("steady state systems"), reports describing compositional homogeneity for products that represent eruptions of more than one event are relatively rare. In support of this, EC-RAFC results indicate that very specific combinations of recharge conditions, bulk distribution coefficients, and element 
concentrations are required to achieve geochemical homogeneity during cooling of a magma body undergoing RAFC. In summary, critical points are that EC-RAFC provides a method to quantitatively investigate complex magmatic systems in a thermodynamic context; it predicts complex, nonmonotonic geochemical trends for which there are natural analogues that have been difficult to model; and finally, ECRAFC establishes the link between the chemical and physical attributes of a magmatic system. Application of EC-RAFC promises to improve our understanding of specific tectonomagmatic systems as well as enhance our grasp of the essential physiochemical principles that govern magma body evolution.

Components: 10,317 words, 16 figures, 3 tables.

Keywords: Energy-constrained; open system; recharge; assimilation; geochemical model; enclave.

Index Terms: 8439 Volcanology: Physics and chemistry of magma bodies; 3640 Mineralogy and Petrology: Igneous petrology; 3670 Mineralogy and Petrology: Minor and trace element composition; 1040 Geochemistry: Isotopic composition/ chemistry.

Received 24 January 2002; Revised 29 July 2002; Accepted 30 August 2002; Published 12 February 2003.

Bohrson, W. A., and F. J. Spera, Energy-constrained open-system magmatic processes IV: Geochemical, thermal and mass consequences of energy-constrained recharge, assimilation and fractional crystallization (EC-RAFC), Geochem. Geophys. Geosyst., 4(2), 8002, doi:10.1029/2002GC000316, 2003.

Guest Editor: Hubert Staudigel

\section{Introduction}

[2] The geochemical diversity of igneous rocks on Earth results from a complex array of processes, many of which occur in magma storage regions (reservoirs) or during vertical or lateral transport within conduits. The record of these processes is preserved in a spectrum of igneous rocks that ranges from rapidly quenched melts to slowly cooled magmas. Major and trace element and isotopic data collected during the last several decades indicate that first-order magma chamber processes include magma recharge (magma replenishment), assimilation, and fractional crystallization (RAFC). Several quantitative models have been developed that predict the geochemical paths of magmas that undergo RAFC [e.g., O'Hara, 1977; O’Hara and Mathews, 1981; Albaréde, 1995; DePaolo, 1985], and application of these models has led to an increasingly sophisticated understanding of magmatic processes.

[3] In this paper, we build upon previous work that describes the theory and application of Energeti-
cally-Constrained Assimilation Fractional Crystallization (EC-AFC), a model which tracks the geochemical, thermal, and mass evolution of magma undergoing concurrent assimilation (of wallrock-derived melt) and fractional crystallization (cumulate formation) in a cooling magma body [Spera and Bohrson, 2001; Bohrson and Spera, 2001]. This model was applied to several natural systems that evolved dominantly by assimilation and fractional crystallization [Bohrson and Spera, 2001]. Abundant evidence suggests that, in general, magma replenishment plays a quantitatively significant role in the generation of the geochemical diversity of igneous rocks in a wide range of settings (e.g., flood basalts, layered mafic intrusions, arcs, mid-ocean ridges, ocean islands). Importantly, it is noted that advection of heat into a standing magma body as well as addition of "fresh" recharge are not independent events. Consequently, the EC-AFC model has been expanded to include the thermal and mass balance implications of magma recharge. The conceptual framework, quantitative development, and assumptions of this new formulation, Energy-Constrained Recharge, 
Assimilation, Fractional Crystallization (ECRAFC), are outlined in Spera and Bohrson [2002]. Briefly, the composite RAFC magmatic system includes three sub-systems: an initially pristine (standing) magma body, wallrock that may produce anatectic melt, and a chemically and thermally distinct reservoir of recharge melt. During the RAFC event, recharge and anatectic melts are assumed to flow into and homogenize with standing magma. If the liquidus temperature of recharge magma is higher than the local temperature of the standing magma, a portion of recharge melt, governed by the recharge melt productivity function, solidifies. In EC-RAFC, these solids are called enclaves, and their compositions are governed by fractional crystallization of pristine recharge melt (for a complete explanation of these enclaves [see Spera and Bohrson, 2002]). Cumulates also form in the magma body as a consequence of cooling. The series of coupled differential equations that comprise EC-RAFC self-consistently tracks the thermal characteristics, masses and compositions of enclaves, cumulates, and melt as the sub-systems approach thermal equilibrium. The ability to monitor the mass and compositions of the solids formed during EC-RAFC events is significant because, compared to liquids (which are assumed to be in chemical equilibrium at each point along the RAFC path), solids record the chronological record of incremental changes in composition during RAFC magmatic evolution.

[4] Results illustrated in this paper outline some of the complexity evident in an EC-RAFC composite system and emphasize insight gained by combining information from melts and solids. Among the many possibilities of petrologic relevance that can be examined with EC-RAFC, we highlight the trace element, isotopic, mass and thermal consequences on solids and melt of episodic versus continuous recharge, variations in the thermodynamic properties of the subsystems, variations in the recharge melt input function, recharge-fractionation dominated systems (RFC), conditions that promote the formation of enclaves versus cumulates, and conditions under which magmatic systems may be chemically homogeneous. In addition, the impact recharge has on the efficacy of assim- ilation is examined. Like EC-AFC, the resultant geochemical paths for solids and melts undergoing EC-RAFC are complex and are often described by non-monotonic element-element, element-isotope trends. A primary goal of this paper is to introduce a range of examples that illustrates this geochemical complexity, particularly because many of the geochemical trends are quite different from those predicted by extant models. The coupled nature of the processes allows specific chemical paths to be associated with defined masses of standing magma and cumulates, recharge magma and enclaves, and assimilant. EC-RAFC therefore provides a tool that links petrologic processes with volume (mass) data of volcanic and plutonic systems. The results presented here emphasize the critical need for integrated field, petrologic and geochemical studies of igneous systems. We suggest that the specificity in geochemical parameter space that results from EC-RAFC simulations will strengthen our ability to decipher the complex interactions among the RAFC sub-systems. Application of EC-RAFC to natural systems is presented in a later study.

\section{Episodic Versus Continuous Recharge}

[5] EC-RAFC accommodates continuous or episodic recharge of melt of distinct composition and thermal characteristics into the standing magma body for a particular RAFC event [Spera and Bohrson, 2002]. The user defines the total mass of recharge magma $\left(\mathrm{M}_{\mathrm{r}}^{\mathrm{o}}\right)$ involved in the RAFC event, as well the cumulative amount of mass addition as a function of temperature (called the recharge melt input function: $M_{r}=f\left(T_{m}\right)$ ). Based in part on geochemical data from temporally welldefined samples, a number of subaerial volcanic systems have been described as characterized by episodic recharge (e.g., Akagi volcano [Umino and Horio, 1998], El Chichon [Tepley et al., 2000], Merapi [Gauthier and Condomines, 1999]). Episodic injection of mafic magma into mid-ocean ridge magma reservoirs is also considered important, as first documented by Dungan and Rhodes [1978] and Rhodes et al. [1979] and as extensively documented by many other investigators since. Geochemical and petrologic data from intrusive 
complexes such as the Muskox [Irvine and Smith, 1967], the Bushveld [Eales and Cawthorn, 1996], the Rum [Emeleus, 1987; Volker and Upton, 1990] and the Ivrea-Verbano Zone [Clemens-Knott et al., 1999] also have been used as evidence for the occurrence of repeated injections of magma into actively evolving magma chambers. In contrast, some volcanic events, such as the 1759-1774 eruption of Jorullo [Luhr and Carmichael, 1985], the 1943-1952 eruption of Paricutin [Wilcox, 1954], the 1972-1974 Mauna Ulu eruption [Tilling et al., 1987], and the 1968-1985 eruption of Arenal [Reagan et al., 1987] have been described as reflecting "steady state" behavior, where magma is apparently supplied continuously to a sub-volcanic reservoir, although possibly at variable rates. Wadge [1982] made the observation that eruptive phases of a number of volcanoes (e.g., Kilauea, Piton de la Fournaise, Arenal, Santiaguito) reflect "steady state" behavior, which he defined as a linear relationship between cumulative volume of erupted magma and time. There is also the suggestion that activity at some volcanoes, particularly those found in arcs, may be controlled by short time-scale episodic recharge events that are superimposed on a background of longer-term continuous replenishment [Gamble et al., 1999]. Based on estimates of magma supply rates for Krafla, Lakagigar, Kilauea, and Mauna Loa, Takada [1999] made the distinction between rift volcanoes, which are intermittently supplied by larger volumes $\left(1-10 \mathrm{~km}^{3}\right)$ of magma over longer time intervals $\left(10^{2}-10^{4}\right.$ years $)$, and intraplate volcanoes, where the magma supply is continuous although the supply rate may fluctuate.

[6] Such descriptions of and inferences about the nature of magma recharge highlight the complications inherent in quantifying this process. Defining and discerning the differences between continuous and episodic recharge require a clear definition of the timescales over which magma is supplied to the sub-volcanic chamber(s). In addition, the incomplete record of magmatism that is preserved renders distinguishing episodic and continuous recharge events a challenge. Despite these hurdles, developing tools that distinguish these two is a worthwhile pursuit because the style of recharge is likely a function of the mechanics of mantle melting and magma ascent and intrusion dynamics. In addition, distinct indicators of the nature of recharge might allow better integration of geochemical and geophysical data collected at active volcanoes. EC-RAFC can be used as a tool to develop quantitative constraints on the mass and geochemical characteristics of continuously versus episodically recharged magma systems.

[7] Table 1 summarizes input parameters for a case where basaltic magma intrudes lower crust of intermediate composition; the crustal geochemical parameters are similar to those for average lower crust cited in Taylor and McLennan [1985]. To illustrate the consequences of intrusion of recharge magma that is compositionally distinct from pristine magma already making up the magma body, recharge magma, which is intruded continuously or episodically as a function of $\mathrm{T}_{\mathrm{m}}$, is assumed to be more mafic than pristine magma, with less radiogenic $\mathrm{Sr}$ and more radiogenic $\mathrm{Nd}$ isotope signatures. Sr is modeled to behave compatibly in pristine and recharge magmas but incompatibly during host rock anatexis. $\mathrm{Nd}$ is incompatible in all sub-systems. For this set of input parameters, because we have (arbitrarily) chosen recharge magma with initial and liquidus temperatures identical to those of pristine magma, a portion of recharge melt chills upon injection and some enclaves form [see Spera and Bohrson, 2002]. Due to enthalpy transport during recharge, the total masses of wallrock involved in the thermal exchange and of anatectic melt produced are greater than they would have been had no recharge occurred. This is therefore an example where recharge enhances assimilation. An interesting observation related to wallrock anatexis is that it initiates at different temperatures for the continuous versus episodic cases. The local magma temperature at which wallrock reaches its solidus is lower in the continuous recharge case $\left(\sim 1103^{\circ} \mathrm{C}\right)$ compared to the episodic recharge case $\left(\sim 1119^{\circ} \mathrm{C}\right)$. This is because at $\sim 1119^{\circ} \mathrm{C}, 99 \%$ of the recharge magma has been added to the standing magma in the episodic case, whereas only $72 \%$ has in the continuous case; the additional latent heat added through crystallization of the episodically recharged 
Table 1. EC-RAFC Parameters for Lower Crustal Continuous and Episodic Recharge Cases

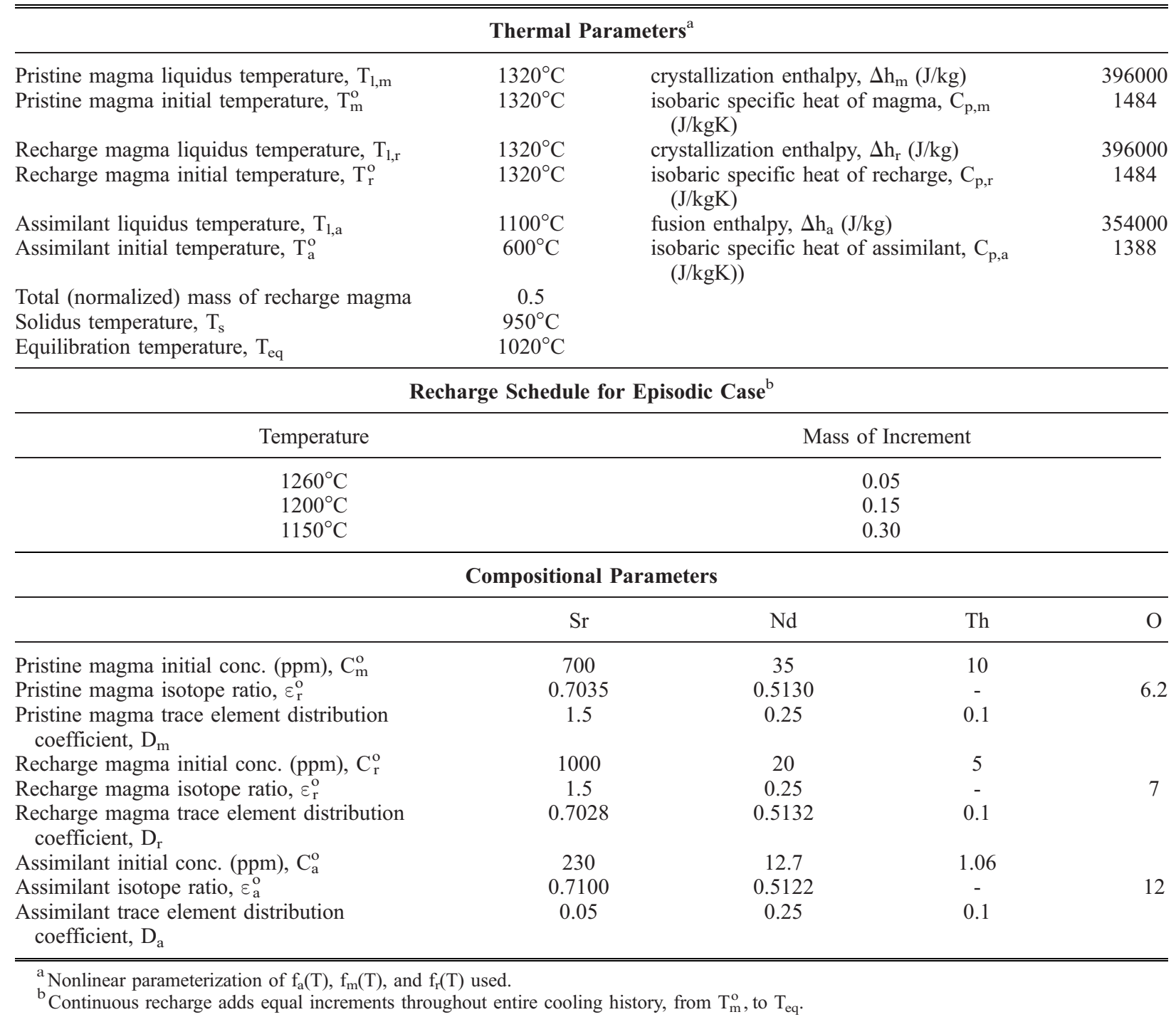

magma allows anatexis to initiate at a higher $\mathrm{T}_{\mathrm{m}}$, a result that makes intuitive sense and underscores the coupled nature of recharge and assimilation.

[8] The geochemical signatures of recharge are distinct, both between the continuous and episodic models and between the recharge and recharge-free (EC-AFC) models (Figure 1). In the cases modeled here, where recharge magma has a $\mathrm{Sr}$ isotope ratio that is less radiogenic than that of the pristine magma (i.e., prior to the onset of assimilation), the ${ }^{87} \mathrm{Sr} /{ }^{86} \mathrm{Sr}$ of the standing magma decreases. In the case of continuous recharge, the $[\mathrm{Sr}]-{ }^{87} \mathrm{Sr} /{ }^{86} \mathrm{Sr}$ change is smooth whereas in the case of episodic recharge, the change can be described as a step- function (inset, Figure 1). At the $\mathrm{T}_{\mathrm{m}}$ where wallrock begins to melt, compared to the episodic case, the continuous recharge case exhibits higher ${ }^{87} \mathrm{Sr} /{ }^{86} \mathrm{Sr}$ and lower [Sr] because less recharge magma has been added to the standing magma body. At $\mathrm{T}_{\mathrm{eq}}$, the continuous case is therefore characterized by ${ }^{87} \mathrm{Sr} /{ }^{86} \mathrm{Sr}$ that is more 'contaminated' (i.e., ${ }^{87} \mathrm{Sr} /{ }^{86} \mathrm{Sr}$ of the magma is closer to that of the wallrock) than the episodic case.

[9] Although the [Sr] versus ${ }^{87} \mathrm{Sr} /{ }^{86} \mathrm{Sr}$ changes associated with recharge (prior to the onset of assimilation) are fairly restricted compared to the total range of these parameters for the entire simulation (to $\mathrm{T}_{\mathrm{eq}}$ ), the range of $\mathrm{T}_{\mathrm{m}}$ over which 


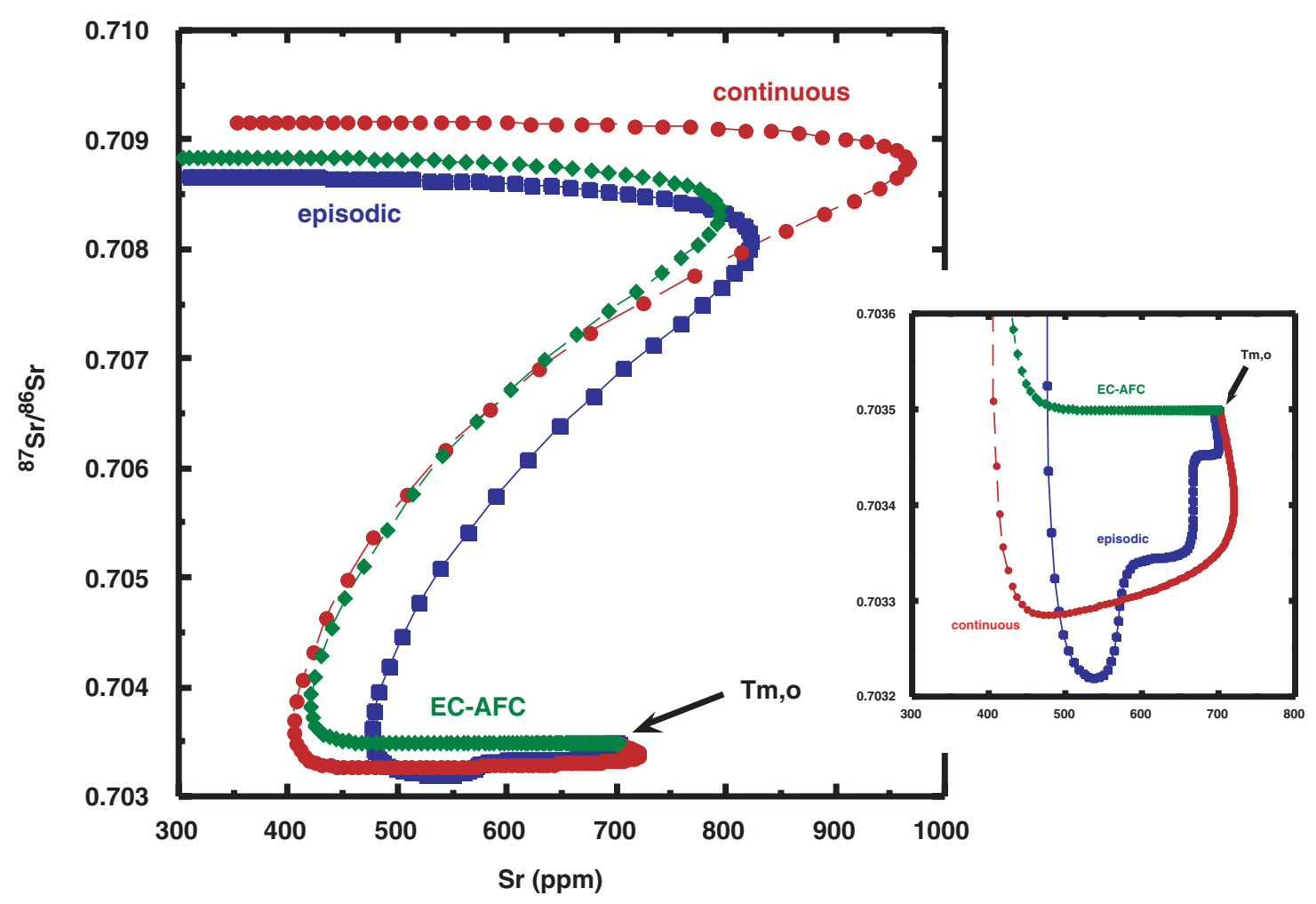

Figure 1. $\mathrm{Sr}(\mathrm{ppm})$ versus ${ }^{87} \mathrm{Sr} /{ }^{86} \mathrm{Sr}$ for episodic and continuous recharge melts for cases presented in Table 1. ECAFC (no recharge) shown for comparison; where appropriate, all parameters are the same as those in Table 1. (inset) Expanded scale to show distinctions among three cases at relatively high $\mathrm{T}_{\mathrm{m}}$. For all simulations in Figure 1 and all subsequent figures, each symbol represents $\sim 1^{\circ} \mathrm{C}$ decrease in $\mathrm{T}_{\mathrm{m}}$.

no assimilation occurs is $\sim 200^{\circ} \mathrm{C}$, about $67 \%$ of the temperature range of the full simulation (from $\mathrm{T}_{\mathrm{m}, \mathrm{o}}$ to $\mathrm{T}_{\mathrm{eq}}$ ). This suggests that there may be a distinct record of recharge that is preserved in the cumulates associated with these reservoirs; at the $\mathrm{T}_{\mathrm{m}}$ at which wallrock reaches its solidus (i.e., assimilation commences), the total (normalized) mass of cumulates for the continuous case is 0.99 and for the episodic case is 0.88 . If eruptions have occurred, this signature of recharge may be preserved in volcanic products as well.

[10] [Nd]- ${ }^{143} \mathrm{Nd} /{ }^{144} \mathrm{Nd}$ (Figure 2) further illustrates the complex, non-monotonic trends that can derive from EC-RAFC processes. The continuous and episodic recharge models are distinct in $\mathrm{Nd}$ concentration-isotope space (Figure 2, inset), as they were in $\mathrm{Sr}$ space. $[\mathrm{Nd}]$ initially increases because it is modeled as incompatible in all sub-systems. For both recharge cases, the isotope ratio initially increases, reflecting the more radiogenic recharge component. The signature of assimilation eventu- ally dominates both cases, and both $[\mathrm{Nd}]$ and ${ }^{143} \mathrm{Nd} /{ }^{144} \mathrm{Nd}$ decrease. The concentration decreases because of a dilution effect imparted by fractional melting of an incompatible element (see discussion in Bohrson and Spera, 2001), and the ${ }^{143} \mathrm{Nd} /{ }^{144} \mathrm{Nd}$ decreases because the assimilant is less radiogenic. Both recharge cases are different from the rechargefree case, although near $\mathrm{T}_{\text {eq }}$, the differences in ${ }^{143} \mathrm{Nd} /{ }^{144} \mathrm{Nd}$ and $[\mathrm{Nd}]$ among the three examples are subtle.

[11] Figure 3 illustrates the variations in [Sr] that may be preserved in solids associated with the episodic recharge case presented in Table 1. It is important to appreciate that the enclaves form directly from recharge magma whereas cumulates form from standing magma; therefore, the compositions of the two types of solids are distinct. Instantaneous concentrations reflect the variations that occur as crystals form at each temperature step in the simulation [Spera and Bohrson, 2002]. The record of these compositional variations may be 


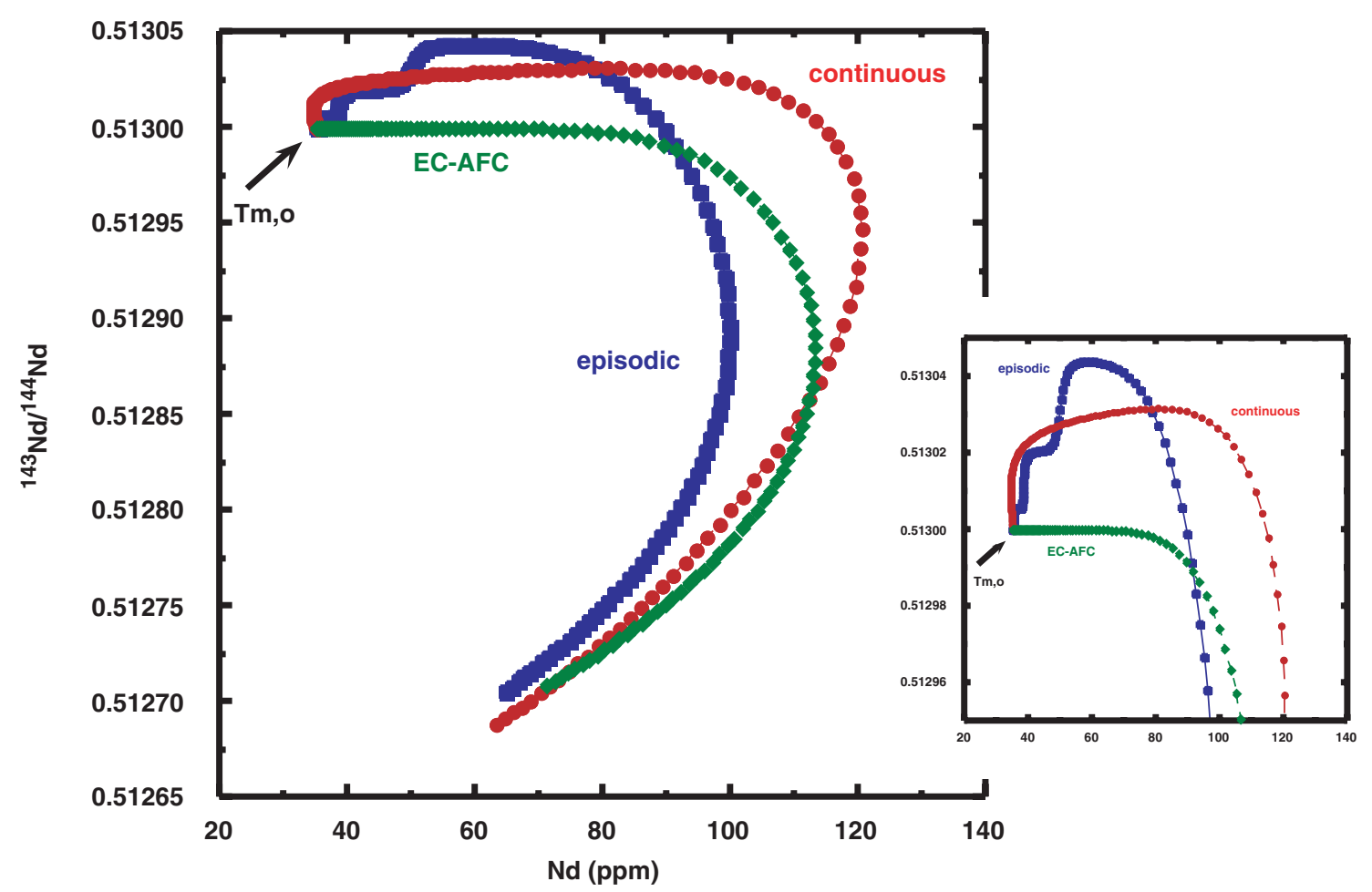

Figure 2. $\mathrm{Nd}(\mathrm{ppm})$ versus ${ }^{143} \mathrm{Nd} /{ }^{144} \mathrm{Nd}$ for episodic and continuous recharge melts for cases presented in Table 1. EC-AFC (no recharge) shown for comparison; where appropriate, all parameters are the same as those in Table 1. (inset) Expanded scale to show distinctions among three cases at relatively high $\mathrm{T}_{\mathrm{m}}$.

evident in enclaves or cumulates sampled on a small spatial scale. Average concentrations [Spera and Bohrson, 2002] for enclaves, cumulates and all solids reflect the compositions of larger spatial scale (e.g., whole rock) samples. Although Figure 3 implies that documenting magma chamber processes using geochemical data from crystalline bodies may be a complicated task, Figures $4 \mathrm{a}$ and $4 \mathrm{~b}$ underscore the important record these processes preserve. These figures compare the $\mathrm{Sr}$ and $\mathrm{Nd}$ average concentration-isotope paths of cumulates that may be preserved for the continuous and episodic cases; in detail, these are distinct, and careful sampling and analysis, coupled with use of EC-RAFC, is illuminating.

\section{Geochemical Trends}

[12] Several additional observations regarding the geochemical trends of EC-RAFC systems are noteworthy. The $[\mathrm{Nd}]-[\mathrm{Sr}]$ melt trends for the episodic and continuous recharge cases outlined in Table 1 are illustrative of one type of element-element trend (Figure 5); the EC-AFC case is shown for comparison. In general, prior to onset of assimilation, in the episodic recharge case, $[\mathrm{Sr}]$ initially decreases (inset, Figure 5) because more of the element is being removed by fractional crystallization than is being added by recharge. In the case of continuous recharge, [Sr] initially increases because recharge is adding more $\mathrm{Sr}$ than is being removed by fractional crystallization. When fractional crystallization dominates, $[\mathrm{Sr}]$ decreases in both recharge cases. Nd initially increases in both recharge cases because it is incompatible in pristine and recharge magmas. When anatectic melt is incorporated, $\mathrm{Sr}$ initially increases in concentration due to the effects of fractional melting. Eventually, however, because both $\mathrm{Nd}$ and $\mathrm{Sr}$ are modeled as incompatible in the wallrock, the dilution effect yields decreases in both $[\mathrm{Sr}]$ and $[\mathrm{Nd}]$. In the absence of consideration of the effects of partial melting and enclave formation, the non-monotonic nature of these trends might not be recognized as evidence of RAFC processes.

[13] $\mathrm{Sr}-\mathrm{Nd}$ and $\mathrm{Sr}-\mathrm{O}$ isotope trends also reflect the integrated effects of EC-RAFC and emphasize a 


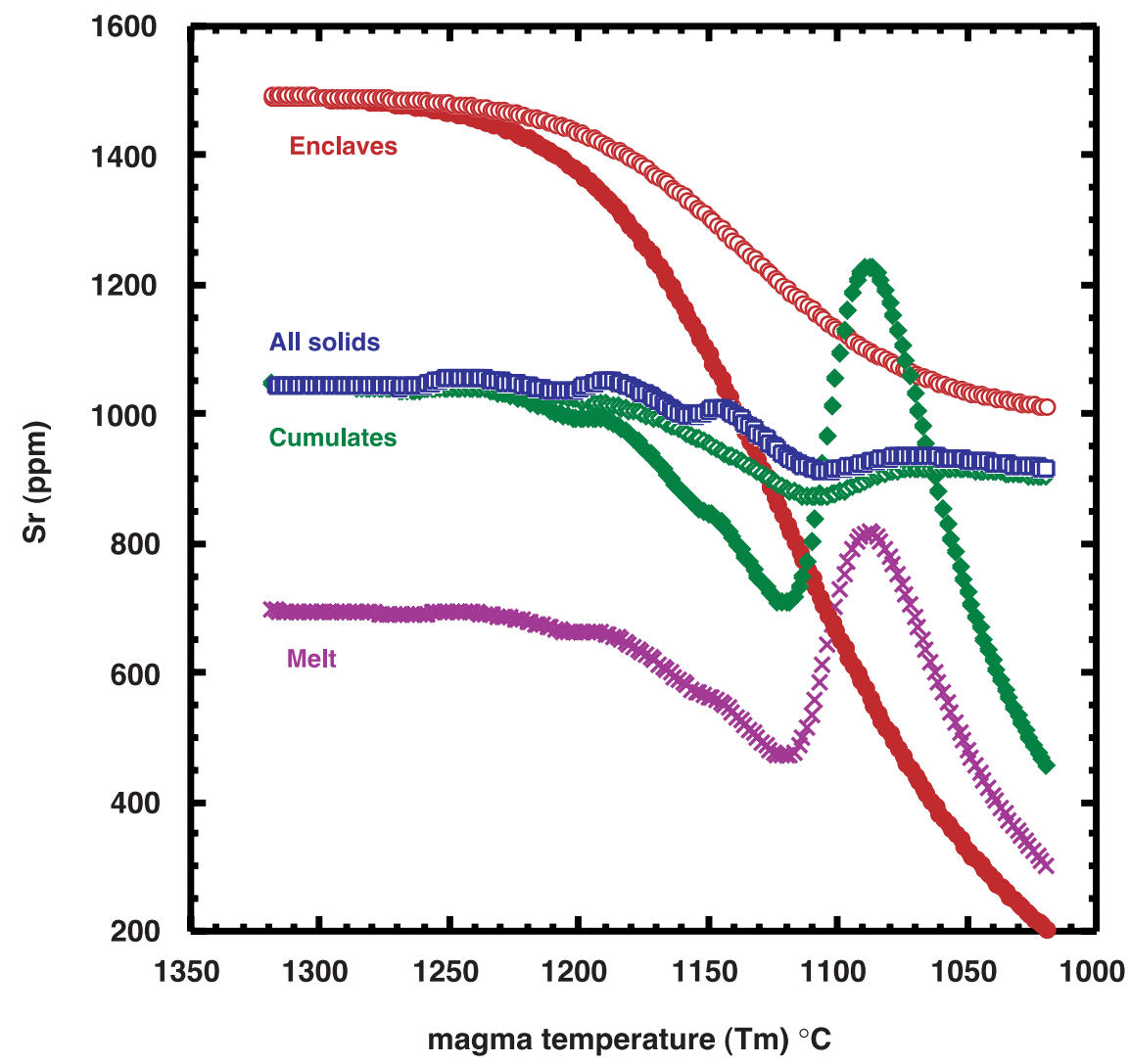

Figure 3. $\mathrm{T}_{\mathrm{m}}$ versus $\mathrm{Sr}(\mathrm{ppm})$ for enclaves, cumulates, and all solids (enclaves + cumulates) for episodic case presented in Table 1. Instantaneous concentrations (closed symbols) reflect [Sr] in new increment of enclave or cumulate formed during temperature decrement $\mathrm{dT}_{\mathrm{m}}$. Average concentration (open symbols) reflects [Sr] in all cumulates, enclaves, or total solids. Melt $[\mathrm{Sr}]-\mathrm{T}_{\mathrm{m}}$ shown for comparison. Instantaneous and average concentration equations for solids presented in Spera and Bohrson [2002].

point made in Bohrson and Spera [2001]. That is, conclusions made regarding the efficacy of particular magma chamber processes based on geochemical trends formulated from models that lack the coupled energy, mass and species conservation approach may lead to incorrect interpretations about the petrogenetic histories of these systems. For example, for the EC-RAFC cases, after the initial increase in ${ }^{143} \mathrm{Nd} /{ }^{144} \mathrm{Nd}$ and decrease in ${ }^{87} \mathrm{Sr} /{ }^{86} \mathrm{Sr}$ due to recharge, ${ }^{143} \mathrm{Nd} /{ }^{144} \mathrm{Nd}$ decreases by only $80-130 \mathrm{ppm}$ while ${ }^{87} \mathrm{Sr} /{ }^{86} \mathrm{Sr}$ increases by $5000 \mathrm{ppm}$ (Figure 6). Then, ${ }^{143} \mathrm{Nd} /{ }^{144} \mathrm{Nd}$ decreases by up to $270 \mathrm{ppm}$ while ${ }^{87} \mathrm{Sr} /{ }^{86} \mathrm{Sr}$ increases by only $\sim 1000 \mathrm{ppm}$. The resulting concave downward curve is opposite of that predicted by application of the AFC [DePaolo, 1981] or two-component mixing equations to the same cases (Figure 6). This difference is important because the nature of the concavity has been used to predict ratios of $\mathrm{Sr} /$ $\mathrm{Nd}_{\text {(melt) }} / \mathrm{Sr} / \mathrm{Nd}_{\text {(contaminant) }}$ for a two component system that includes crustal-derived and mantlederived end-members [DePaolo and Wasserburg, 1979]. In these examples, this ratio is $>1$. However, for ratios $>1$, other formulations (e.g., DePaolo [1981] and simple two-component mixing) yield concave upward curves. The key point is that the concavity of these curves can not be interpreted based solely upon initial values of the two endmembers; instead, they reflect the integrated effects of assimilation, recharge, and cumulate formation, processes linked through energy conservation. Results of O-Sr isotopes further underscore the problems inherent in using these types of plots to predict characteristics about sub-systems or processes. The EC-RAFC Sr-O isotope curves for these cases are concave upwards (Figure 7), a 

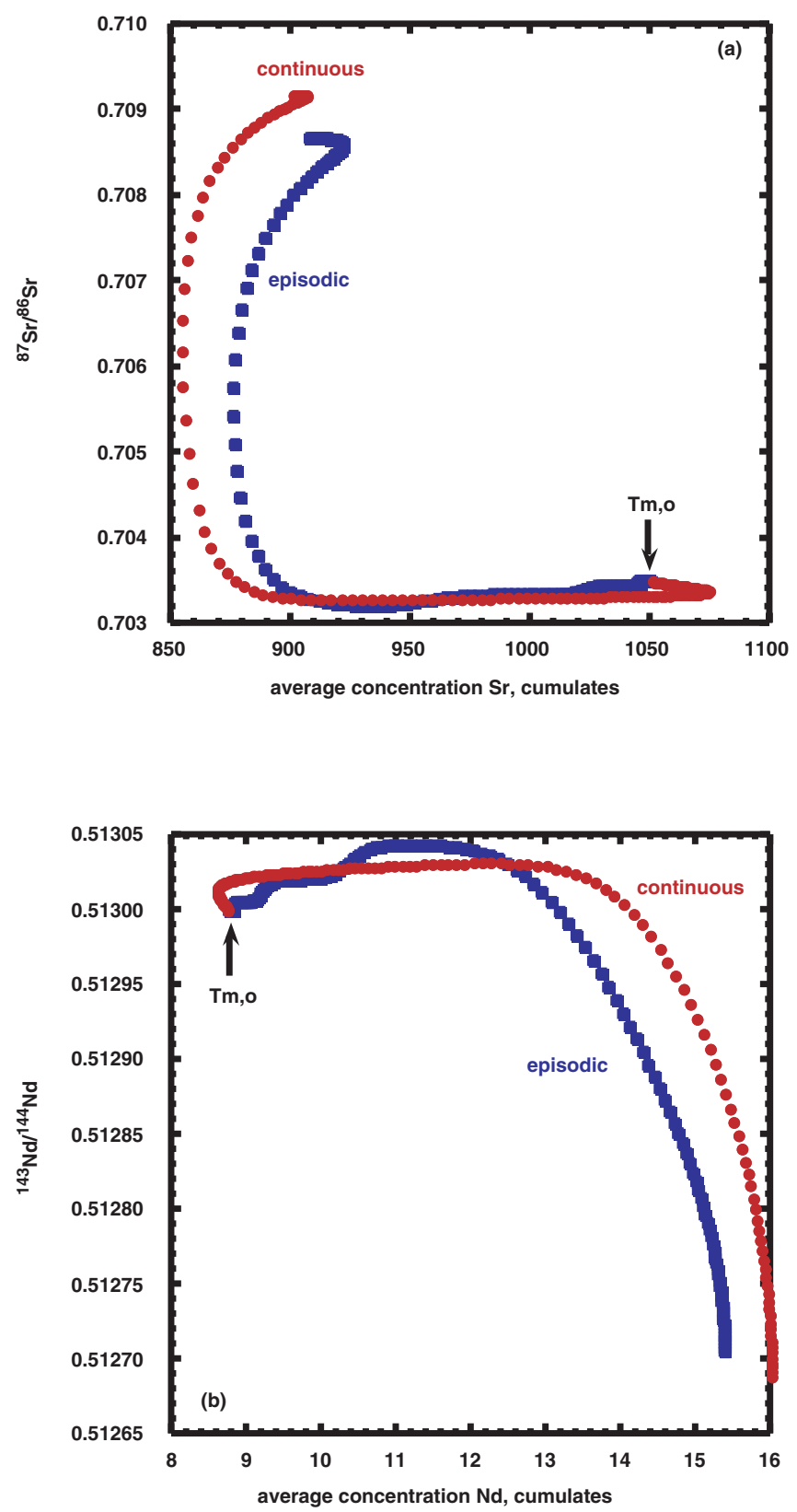

Figure 4. Comparison between (a) average Sr concentration (ppm) ${ }^{87} \mathrm{Sr} r{ }^{86} \mathrm{Sr}$, and (b) average Nd concentration (ppm) $-{ }^{143} \mathrm{Nd} /{ }^{144} \mathrm{Nd}$ in cumulates for episodic and continuous recharge cases presented in Table 1.

curvature that has been attributed to source contamination rather than crustal contamination [e.g., Taylor, 1980; James, 1981]. Additional studies using Sr-O isotopes [e.g., Magaritz et al., 1978; Benito et al., 1999], as well as other isotope pairs [e.g., Leat et al., 1991; Molzahn et al., 1996], have made conclusions about source versus crustal level contamination, at least in part, based on the shapes of such isotope-isotope trends. Although the con- clusions in these and other studies may be correct, it is clear that EC-RAFC simulations can yield isotope-isotope trends that traditionally have been interpreted to represent source contamination, and therefore reexamination of these cases may be fruitful. It is also important to note that a number of authors have made similar observations regarding the interpretations of $\mathrm{Sr}-\mathrm{O}$ isotope diagrams [e.g., Davidson et al., 1991; Vroon et al., 1993]: 


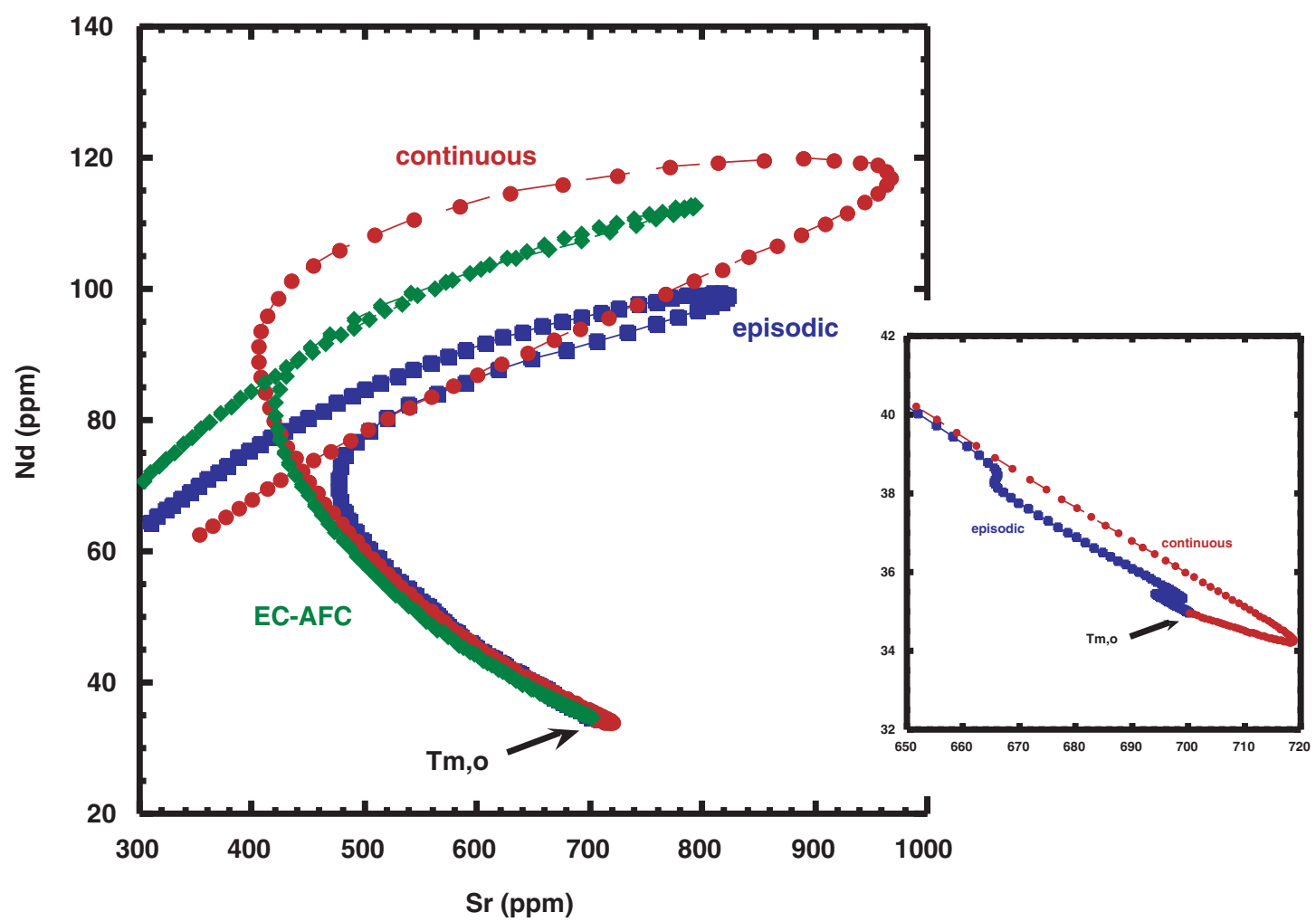

Figure 5. $\mathrm{Sr}(\mathrm{ppm})$ versus $\mathrm{Nd}(\mathrm{ppm})$ for episodic and continuous recharge melts for cases presented in Table 1. For comparison, EC-AFC case is included. (inset) Expanded scale to show changes in $[\mathrm{Sr}]$ at relatively high $\mathrm{T}_{\mathrm{m}}$.

they note that if $\mathrm{Sr}$ behaves incompatibly in the magma, then a concave upward trend could be explained by crustal contamination rather than source contamination. While this is correct, it is important to recognize the EC-RAFC yields this concavity even in cases where $\mathrm{Sr}$ is compatible in standing magma.

\section{Effects of Varying Equilibration Temperature and Recharge Mass Input Characteristics}

[14] This section illustrates the importance of incorporating thermodynamic data into quantification of magma chamber processes. The essential observation is that the equilibration temperature $\left(\mathrm{T}_{\mathrm{eq}}\right)$ and the recharge melt input function $\left(\mathrm{M}_{\mathrm{r}}=\right.$ $\mathrm{f}(\mathrm{Tm}))$ are fundamental parameters that have impact on the geochemistry of a magmatic system. For example, results from the recharge cases presented in Table $1\left(\mathrm{~T}_{\mathrm{eq}}=1020^{\circ} \mathrm{C}\right)$ are compared with cases where all parameters are the same except $\mathrm{T}_{\text {eq }}$ is $\sim 100^{\circ}$ higher $\left(1120^{\circ} \mathrm{C}\right)$. The total mass of wallrock involved in the RAFC event, $\mathrm{M}_{\mathrm{a}}^{\mathrm{o}}$, is much smaller in the $1120^{\circ} \mathrm{C}$ cases compared to the $1020^{\circ} \mathrm{C}$ cases ( 0.79 versus 1.76 , respectively), and therefore assimilation begins at a higher $\mathrm{T}_{\mathrm{m}}$ in the $1120^{\circ} \mathrm{C}$ cases. As a consequence, both $1120^{\circ} \mathrm{C}$ cases have higher $[\mathrm{Sr}$ ] when assimilation commences (inset, Figure 8), and at $\mathrm{T}_{\text {eq }},{ }^{87} \mathrm{Sr} /{ }^{86} \mathrm{Sr}$ is lower than for the $1020^{\circ} \mathrm{C}$ cases (Figure 8).

[15] Because the melt productivity function is generally non-linear, $[\mathrm{Sr}]$ in the continuous $1120^{\circ} \mathrm{C}$ case initially increases (inset, Figure 8) due to addition of recharge $\mathrm{Sr}$ in the absence of substantive fractional crystallization. When fractionation becomes significant, $\mathrm{Sr}$ is removed in greater abundance than is being added by recharge, and [Sr] decreases. (The same effect is observed in the continuous $1020^{\circ}$ RAFC case, although the magnitude is smaller). In both cases of episodic recharge, by the $T_{m}$ at which the first pulse of recharge 


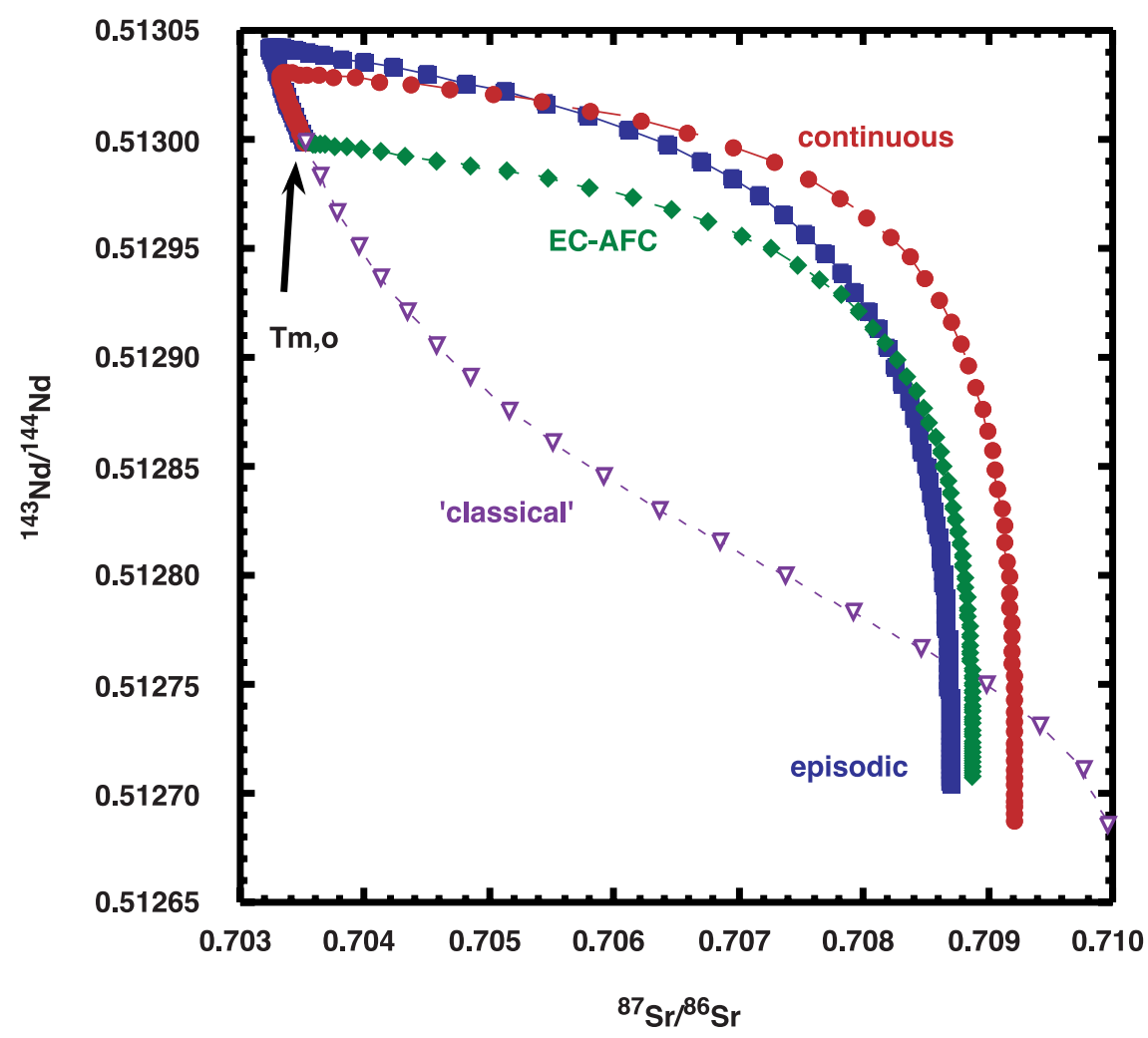

Figure 6. ${ }^{87} \mathrm{Sr} /{ }^{86} \mathrm{Sr}$ versus ${ }^{143} \mathrm{Nd} /{ }^{144} \mathrm{Nd}$ for episodic and continuous recharge melts for cases presented in Table 1. For comparison, EC-AFC case is included. In addition, an AFC trend (called "classical"), modeled using equations of DePaolo [1981], is included. Where relevant, all parameters are similar to those in Table 1. The $r$ for this case is 0.53 , and each symbol represents a decrease in $F$ of 0.05 . Note concavity is opposite for EC-RAFC and "classical" AFC.

magma intrudes, fractionation has extracted more $\mathrm{Sr}$ than is added by recharge, and $[\mathrm{Sr}]$ is therefore lower than the initial value.

[16] Because the recharge melt input function was not modified, a separate effect can be discerned in the $1120^{\circ} \mathrm{C}$ episodic case. The last pulse of recharge initiates at $1150^{\circ} \mathrm{C}$, only $30^{\circ} \mathrm{C}$ above $\mathrm{T}_{\text {eq }}$ (compared to $130^{\circ} \mathrm{C}$ in the $1020^{\circ} \mathrm{C}$ case). At this $\mathrm{T}_{\mathrm{m}}$, a relatively large normalized mass of recharge magma is intruded (0.30), but due to the dilution effect for Sr that results from fractional melting of the wallrock, the mass of $\mathrm{Sr}$ entering the standing magma from assimilation is relatively small. The $\mathrm{Sr}$ added from recharge therefore has a proportionally larger effect, and the outcome is a decrease in ${ }^{87} \mathrm{Sr} /{ }^{86} \mathrm{Sr}$ at a late stage $\left(\mathrm{T}_{\mathrm{m}}\right.$ close to $\left.\mathrm{T}_{\mathrm{eq}}\right)$ in the RAFC event (Figure 8). This demonstrates that the $\mathrm{T}_{\mathrm{m}}$ at which a recharge pulse occurs is a critical parameter in modeling an RAFC event. The char- acteristics of the recharge magma will be more apparent in cases where the mass of $\mathrm{Sr}$ being added by anatectic melt is relatively small. In contrast, in the $1020^{\circ} \mathrm{C}$ case, this effect is not observed because the last pulse of recharge occurs at a $\mathrm{T}_{\mathrm{m}}$ at which the dilution effect has not become significant (Figure 8 ). The inset to Figure 8 also illustrates that, at the onset of wallrock partial melting, the difference in the recharge schedule in the $1120^{\circ} \mathrm{C}$ case yields a lower [Sr] and a slightly higher ${ }^{87} \mathrm{Sr} /{ }^{86} \mathrm{Sr}$ for the episodic recharge case compared to the continuous case. Therefore, at $\mathrm{T}_{\text {eq }},{ }^{87} \mathrm{Sr} /{ }^{86} \mathrm{Sr}$ of the episodic case is higher than that of the continuous case. The opposite is observed in the $1020^{\circ} \mathrm{C}$ cases.

\section{Recharge-Dominated Systems: RFC}

[17] There are particular tectonic settings where, because of the composition of the crust and local 


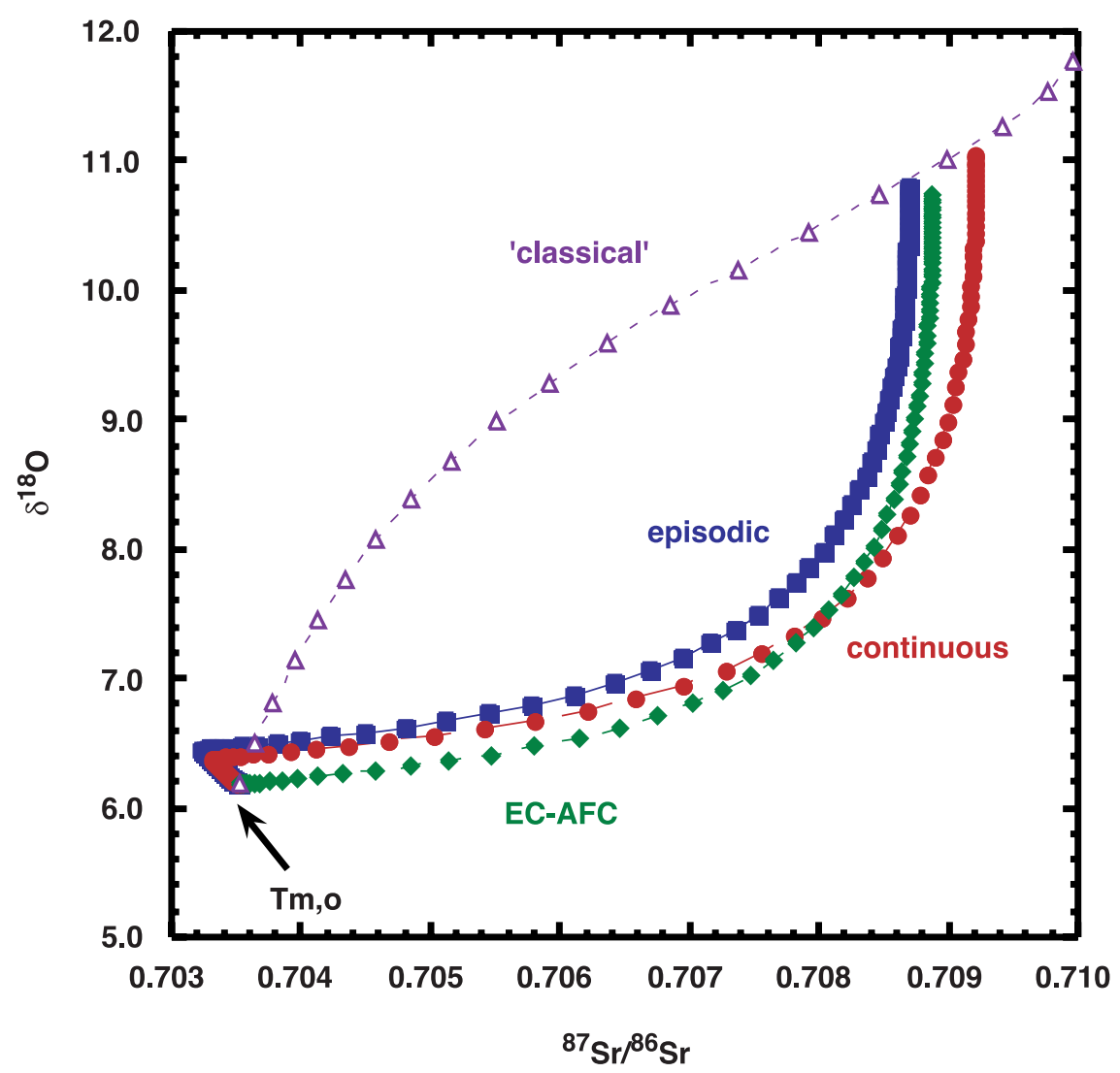

Figure 7. ${ }^{87} \mathrm{Sr} /{ }^{86} \mathrm{Sr}$ versus $\delta^{18} \mathrm{O}$ for episodic and continuous recharge melts for cases presented in Table 1. For comparison, EC-AFC case is included. In addition, an AFC trend (called "classical"), modeled using equations of DePaolo [1981], is included. Where relevant, all parameters are similar to those in Table 1. The $r$ for this case is 0.53 , and each symbol represents a decrease in $F$ of 0.05 . Note concavity is opposite for EC-RAFC versus "classical" AFC.

stress field (e.g., extensional regime), the magmatic system is dominated by recharge and fractional crystallization (RFC) rather than RAFC. An equally plausible scenario in which RFC would dominate is the case where the anatectic melt extraction efficiency ( $\chi$; see Spera and Bohrson [2001]) approaches 0; that is, although anatectic melt is indeed generated in the host, little or none of it is able to mix with standing magma. In the example below, a recharge-dominated system is simulated by artificially setting the assimilant liquidus temperature to an unrealistically high value $\left(\sim 3000^{\circ} \mathrm{C}\right)$ in order to suppress generation of anatectic melt until late (i.e., $\mathrm{T}_{\mathrm{m}}$ near $\mathrm{T}_{\mathrm{eq}}$ ) in the RAFC event. It is important to note that even though no anatectic melt is generated or assimilated, the energy balance still is explicitly considered. That is, heat is still extracted from magma to heat wallrock. This is an example where the heatmass coupling is constrained by the melting characteristics of the wallrock.

[18] The first example of RFC illustrates continuous and episodic cases where more mafic, isotopically less enriched magma recharges a basaltic system located in crust that, for most of the RFC event, does not generate anatectic melt (Figure 9). The equilibration temperature for these cases is $\sim 1120^{\circ} \mathrm{C}$. For comparison, results of the RAFC $1120^{\circ} \mathrm{C}$ cases (i.e., $\mathrm{T}_{1, \mathrm{a}}=1100^{\circ} \mathrm{C}$ instead of $3000^{\circ} \mathrm{C}$ ) discussed above are included. ${ }^{87} \mathrm{Sr} /{ }^{86} \mathrm{Sr}$ initially decreases for both RFC recharge cases, reflecting the less radiogenic ${ }^{87} \mathrm{Sr} /{ }^{86} \mathrm{Sr}$ of recharge magma. For most of the magmatic histories of the systems, at the same $T_{m}$, the continuous recharge case has higher $[\mathrm{Sr}]$ and lower ${ }^{87} \mathrm{Sr} /{ }^{86} \mathrm{Sr}$ compared 


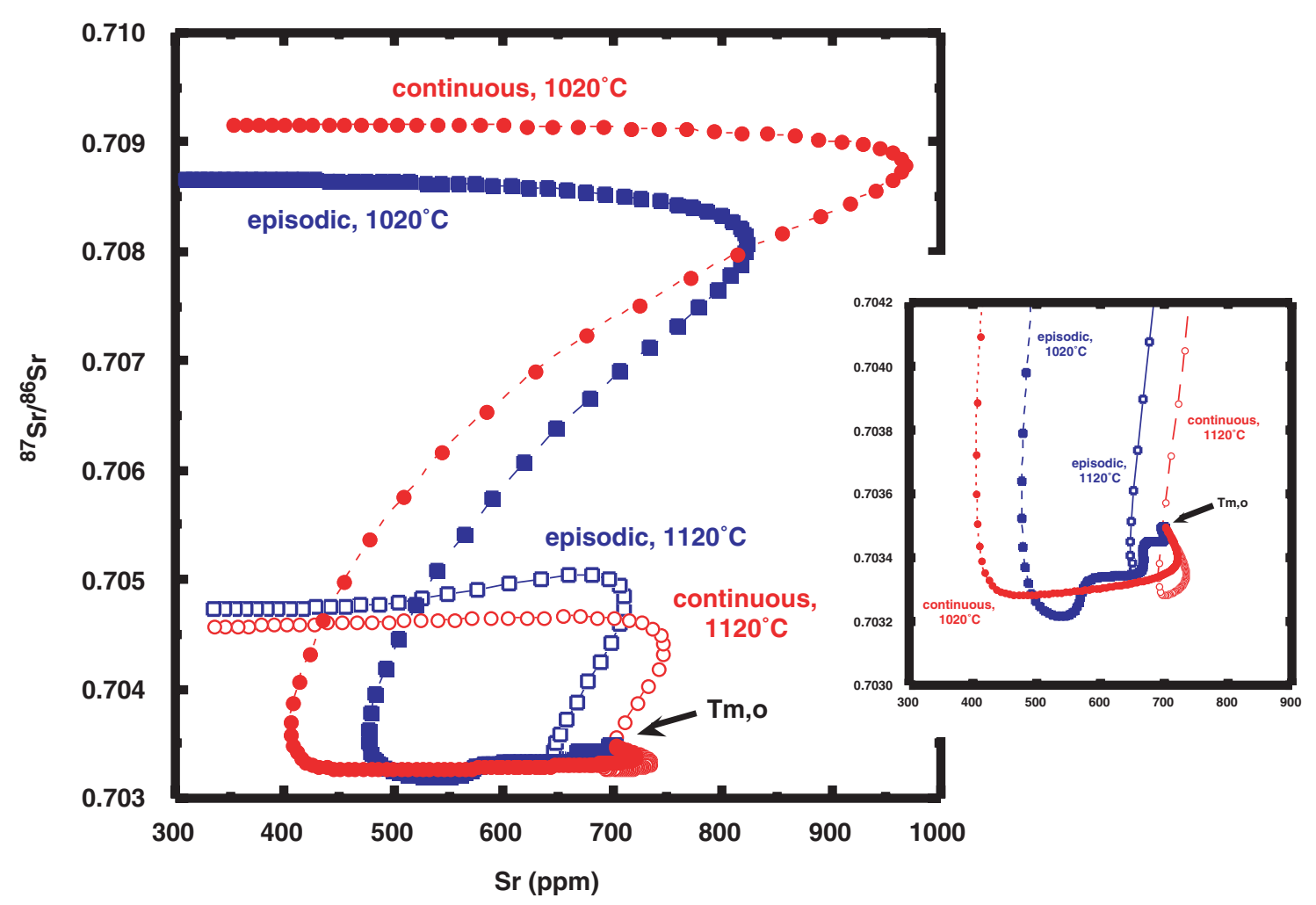

Figure 8. $\mathrm{Sr}(\mathrm{ppm})$ versus ${ }^{87} \mathrm{Sr} /{ }^{86} \mathrm{Sr}$ for episodic and continuous recharge melts for cases presented in Table $1\left(\mathrm{~T}_{\mathrm{eq}}=\right.$ $1020^{\circ} \mathrm{C}$ ), and for episodic and continuous recharge melts for cases where all parameters are the same except $\mathrm{T}_{\mathrm{eq}}=$ $1120^{\circ} \mathrm{C}$. (inset) Expanded scale to show variations in $\mathrm{Sr}(\mathrm{ppm})$ versus ${ }^{87} \mathrm{Sr} /{ }^{86} \mathrm{Sr}$ for four cases.

to the episodic case because the added mass of recharge magma is greater. When anatexis commences, both [Sr] and ${ }^{87} \mathrm{Sr} /{ }^{86} \mathrm{Sr}$ increase, in response to the effects of fractional melting of wallrock with a more radiogenic $\mathrm{Sr}$ isotope signature. However, compared to the $1120^{\circ} \mathrm{C}$ RAFC cases, the ranges of $[\mathrm{Sr}]$ and ${ }^{87} \mathrm{Sr} /{ }^{86} \mathrm{Sr}$ for the RFC cases are small because onset of wallrock melting is delayed to a much lower $T_{m}$.

[19] The $[\mathrm{Nd}]-{ }^{143} \mathrm{Nd} /{ }^{144} \mathrm{Nd}$ trends (Figure 10) are also profoundly different between the EC-RFC and EC-RAFC cases. The RFC cases show a relatively narrow range of $\mathrm{Nd}$ isotope signatures coupled with a large range of $[\mathrm{Nd}]$; this reflects the incompatible nature of $\mathrm{Nd}$ in both standing and recharge magmas. Because the total fraction of melting of wallrock that occurs in the RFC case is very small, the dilution effect is not observed in the RFC cases. The RAFC cases describe larger ranges of ${ }^{143} \mathrm{Nd} /{ }^{144} \mathrm{Nd}$ but smaller ranges of [Nd].
[20] A separate case examines the behavior of a recharge-dominated system in which the mafic recharge magma is isotopically enriched in ${ }^{87} \mathrm{Sr}$ compared to pristine magma. Such a case might represent recharge of melt derived from a lithospheric source. For the RFC simulations, all parameters are the same as the above RFC cases except that ${ }^{87} \mathrm{Sr} /{ }^{86} \mathrm{Sr}$ of the recharge magma is more radiogenic (0.7050). Because a common consequence of $\mathrm{AFC}$ is an increase in ${ }^{87} \mathrm{Sr} /{ }^{86} \mathrm{Sr}$, two EC-AFC comparison cases are shown in which $\mathrm{T}_{\mathrm{eq}}$ is also $1120^{\circ} \mathrm{C}$. One has a wallrock bulk distribution coefficient for $\mathrm{Sr}\left(\mathrm{D}_{\mathrm{Sr}}\right)$ of 0.05 and the other has $\mathrm{D}_{\mathrm{Sr}}$ of 1.5. All other parameters, where appropriate, are the same as the RFC cases. From $\mathrm{T}_{\mathrm{m}, \mathrm{o}}$, the continuous RFC case shows a smooth increase in $[\mathrm{Sr}]$ followed at lower $\mathrm{T}_{\mathrm{m}}$ by a smooth decrease (Figure 11a); this change in trajectory reflects a competition between $\mathrm{Sr}$ addition by recharge and Sr removal by fractional crystallization. Changes in [Sr] in the episodic case also reflect this competi- 


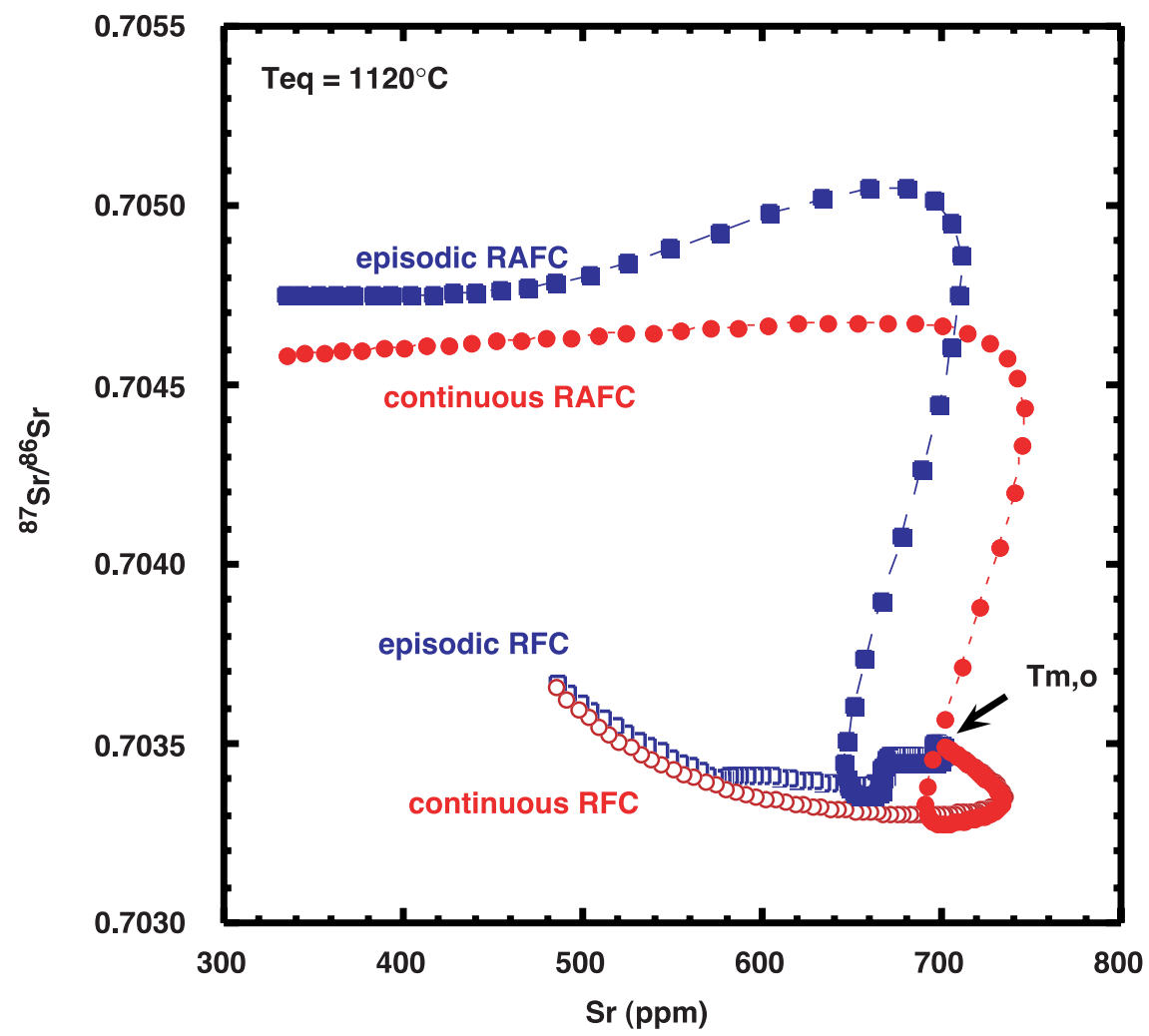

Figure 9. $\mathrm{Sr}$ (ppm) versus ${ }^{87} \mathrm{Sr} /{ }^{86} \mathrm{Sr}$ for episodic and continuous recharge melts for RAFC cases where all parameters are the same as presented in Table 1, except $\mathrm{T}_{\mathrm{eq}}=1120^{\circ} \mathrm{C}$. For comparison, episodic and continuous RFC cases are shown where $\mathrm{T}_{\mathrm{eq}}=1120^{\circ} \mathrm{C}$ and $\mathrm{T}_{1, \mathrm{a}}=3000^{\circ} \mathrm{C}$. This high liquidus suppresses formation of anatectic melt until relatively low $\mathrm{T}_{\mathrm{m}}$.

tion, but the result is distinct decreases in [Sr] when crystallization dominates and slight increases or smaller decreases when the pulse of recharge occurs. In both cases, from $\mathrm{T}_{\mathrm{m}, \mathrm{o}}$ to $\mathrm{T}_{\mathrm{eq}},{ }^{87} \mathrm{Sr} /{ }^{86} \mathrm{Sr}$ increases. Very different [Sr] patterns are evident for the EC-AFC cases because, initially fractional crystallization is dominant. In the EC-AFC case where $\mathrm{D}_{\mathrm{Sr}}$ is 0.05 , when wallrock partial melting commences, $[\mathrm{Sr}]$ increases, but at lower $\mathrm{T}_{\mathrm{m}}$, it decreases because of the dilution effect. In the case where $\mathrm{D}_{\mathrm{Sr}}$ is $1.5,[\mathrm{Sr}]$ decreases throughout the simulation. At $\mathrm{T}_{\text {eq }},{ }^{87} \mathrm{Sr} /{ }^{86} \mathrm{Sr}$ is higher for the ECAFC cases because the total mass of assimilant is greater. Like the melts, the cumulates also preserve a distinct record of recharge by a magma with relatively high $\mathrm{Sr}$ isotope signature (Figure 11b). The critical observation derived from these comparisons is that, even in cases where the recharge magma has ${ }^{87} \mathrm{Sr} /{ }^{86} \mathrm{Sr}$ higher than that of the pristine magma, there may be clear geochemical indicators that will allow RFC and AFC processes to be distinguished.

\section{In Situ Evidence of Magma Recharge: Preservation of Enclaves}

[21] A number of volcanic (e.g., Crater Lake, Medicine Lake Highland [Eichelberger, 1980], Coso volcanic field [Bacon and Metz, 1984], Monte Arci [Montanini et al., 1994], 1915 Lassen eruption [Clynne, 1999], Mt. Dutton [Miller et al., 1999]) and plutonic (Eagle Lake, California, [Furman and Spera, 1985], Cowra Granodiorite, Lachlan Fold Belt [Waight et al., 2001], Vinalhaven [Wiebe et al., 2001]) systems preserve crystalline inclusions or sheets characterized by a range of textural (e.g., chilled margins, pillow-like morphology, fine-grained) and geochemical traits that suggest they represent recharge of hotter, more mafic magma into a standing, more composition- 


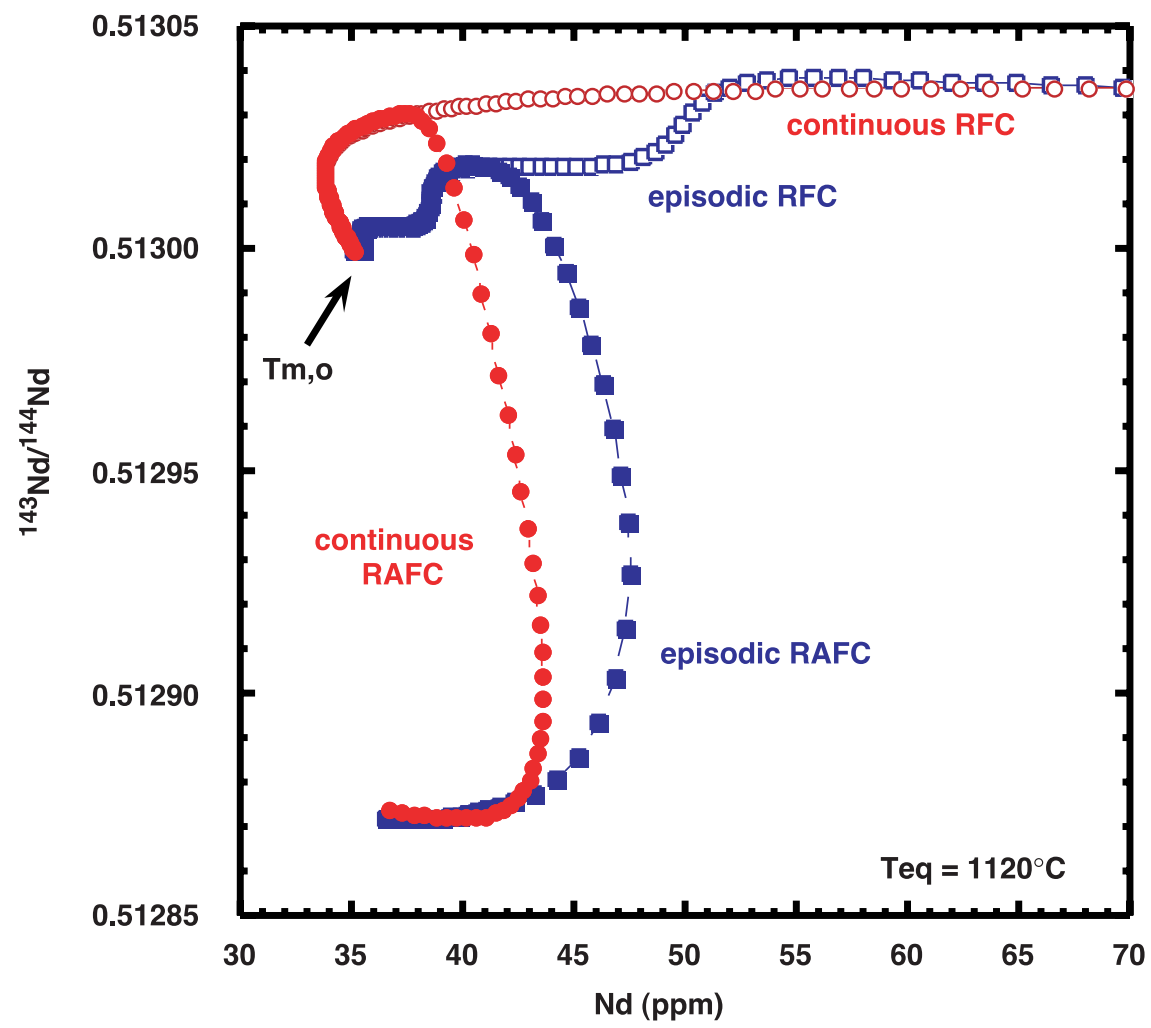

Figure 10. $\mathrm{Nd}(\mathrm{ppm})$ versus ${ }^{143} \mathrm{Nd} /{ }^{144} \mathrm{Nd}$ for episodic and continuous recharge melts for RAFC cases where all parameters are the same as those presented in Table 1 , except $\mathrm{T}_{\mathrm{eq}}=1120^{\circ} \mathrm{C}$. For comparison, episodic and continuous RFC cases are shown where $\mathrm{T}_{\mathrm{eq}}=1120^{\circ} \mathrm{C}$ and $\mathrm{T}_{1, \mathrm{a}}=3000^{\circ} \mathrm{C}$.

ally evolved magma body. The prevalence of these mafic enclaves or sheets attests to the importance of magma recharge in igneous systems. Textural evidence indicates that, rather than undergoing complete homogenization with host magma, some proportion of the hotter recharge magma can quench in the host. EC-RAFC has the facility to predict not only the composition of melts and associated enclaves (or sheets) but also the masses of each that form under a range of thermal conditions. This ability affords the opportunity to constrain the mass, energetic and chemical characteristics of enclave-bearing volcanic and plutonic systems in a way not previously available.

[22] Episodic and continuous recharge of two cases with different histories of enclave formation are compared; one has recharge magma initial and liquidus temperature $\left(1400^{\circ} \mathrm{C}\right)$ that is higher than the initial and liquidus temperature of pristine magma $\left(1320^{\circ} \mathrm{C}\right)$ and the second has recharge magma initial and liquidus temperature that is lower $\left(1250^{\circ} \mathrm{C}\right)$ than the initial and liquidus temperature of pristine magma. Compared to the $1250^{\circ} \mathrm{C}$ cases, hotter recharge magma of the $1400^{\circ} \mathrm{C}$ cases yields a higher mass of enclaves, and the additional latent heat yields involvement of a higher mass of wallrock and anatectic melt. For the $1400^{\circ} \mathrm{C}$ cases, because the mass of enclaves per temperature interval is larger than that for the $1250^{\circ} \mathrm{C}$ cases, the mass of recharge melt added to the standing magma body is less; therefore the total mass of cumulates that form during the RAFC event is slightly lower. For episodic and continuous recharge input for the two different cases, Table 2 compares the final masses of wallrock involved in the event, anatectic melt assimilated, enclaves formed, and cumulates formed. These results suggest that enclave formation is favored by recharge magma that intrudes at a temperature higher than the initial temperature of the standing magma body, 

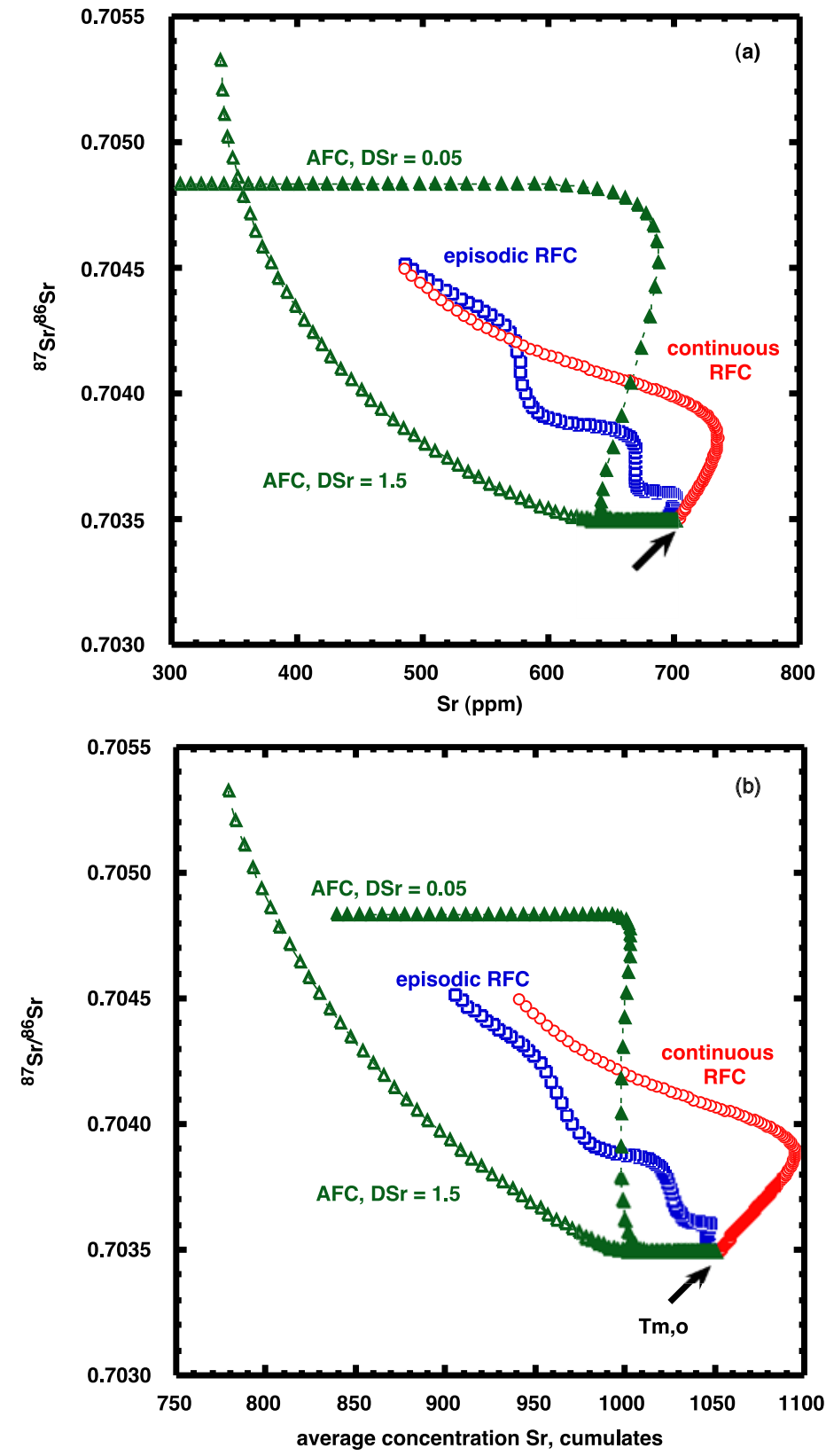

Figure 11. (a) $\mathrm{Sr}(\mathrm{ppm})$ versus ${ }^{87} \mathrm{Sr} /{ }^{86} \mathrm{Sr}$ for melt and (b) average $\mathrm{Sr}(\mathrm{ppm})$ versus ${ }^{87} \mathrm{Sr} /{ }^{86} \mathrm{Sr}$ for cumulates for RFC cases where the $\mathrm{Sr}$ isotope ratio of recharge magma (0.7050) is higher than that of pristine magma (0.7035). Melt and cumulate results for two EC-AFC cases are shown for comparison, one in which $\mathrm{D}_{\mathrm{Sr}}$ (wallrock) $=0.05$ and the second in which $\mathrm{D}_{\mathrm{Sr}}$ (wallrock) $=1.5$.

whereas cumulate formation is favored when recharge magma is at a lower temperature. This result implies that there may be a great deal of information that can be extracted about the characteristics of the recharge magma given tightly constrained field-geochemical studies of volcanic suites and exhumed intrusions.
[23] It is critical to appreciate that distinctions in enclave composition for the cases discussed here may be difficult to detect because the initial composition of each recharge magma increment is equivalent. Thus, the isotope ratios for all enclaves will be the same as the initial isotope signatures of recharge magma, and the $[\mathrm{Sr}]-[\mathrm{Nd}]$ trends for these 
Table 2. Comparison of Selected Normalized Mass Parameters for Different Initial and Liquidus Temperatures of Recharge Magma

\begin{tabular}{lcccc}
\hline & $1400^{\circ} \mathrm{C}$, episodic & $1400^{\circ} \mathrm{C}$, continuous & $1250^{\circ} \mathrm{C}$, episodic & $1250^{\circ} \mathrm{C}$, continuous \\
\hline $\mathrm{M}_{\mathrm{a}}{ }^{\mathrm{o}}$ & 1.85 & 1.85 & 1.66 & 1.66 \\
$\mathrm{M}_{\mathrm{a}}{ }^{*}$ & 0.66 & 0.66 & 0.59 & 0.59 \\
$\mathrm{M}_{\text {en }}$ & 0.30 & 0.28 & 0.06 & 0.15 \\
$\mathrm{M}_{\text {ct }}$ & 1.18 & 1.20 & 1.41 & 1.32 \\
\hline
\end{tabular}

cases are similar. Obviously, recharge magma of distinct composition would produce enclaves of distinct composition.

[24] Figure 12a illustrates standing melt [Sr]${ }^{87} \mathrm{Sr} /{ }^{86} \mathrm{Sr}$ trends for the $1250{ }^{\circ} \mathrm{C}$ and $1400^{\circ} \mathrm{C}$ episodic and continuous recharge cases; the $1320^{\circ} \mathrm{C}$ case is excluded for clarity. The $1400^{\circ} \mathrm{C}$ cases differ from the $1250^{\circ} \mathrm{C}$ cases because different masses of enclaves are produced, which, in turn, results in different masses of recharge melt entering the standing magma body. The episodic cases differ from the continuous cases because of the coupled nature of the non-linear productivity function for recharge magma and the recharge melt input function $\left(\mathrm{M}_{\mathrm{r}}=\mathrm{f}\left(\mathrm{T}_{\mathrm{m}}\right)\right)$. The outcome of the integration of these factors is that, by the $T_{m}$ at which assimilation begins, the episodic $1250^{\circ} \mathrm{C}$ case has incorporated the most recharge melt and the most recharge Sr; thus, the standing magma has the lowest ${ }^{87} \mathrm{Sr} /{ }^{86} \mathrm{Sr}$ and the highest [Sr] (inset, Figure 12a). One consequence of this is that at $\mathrm{T}_{\text {eq }}$, the $1250^{\circ} \mathrm{C}$ episodic case has the least crust-like $\mathrm{Sr}$ isotope ratio. At $\mathrm{T}_{\mathrm{eq}}$, the $1400^{\circ} \mathrm{C}$ continuous recharge case is the most crust-like because of the combined effects of fractional crystallization and the relatively small mass of recharge magma added to the standing magma body by the $\mathrm{T}_{\mathrm{m}}$ at which anatexis commences. Assimilation commences at the highest $\mathrm{T}_{\mathrm{m}}$ in the $1400^{\circ} \mathrm{C}$ episodic case because of two factors: the first is that by a $T_{m}$ near the solidus, more recharge magma has been added in the episodic cases than in the continuous cases, and the second is that the specific enthalpy of recharge is higher for $\mathrm{T}_{\mathrm{r}}^{\mathrm{o}}=1400^{\circ} \mathrm{C}$ compared to the $1250^{\circ} \mathrm{C}$ case.

[25] The geochemical records in the cumulates (and total solids) also preserve distinctions between the $1250^{\circ} \mathrm{C}$ and $1400^{\circ} \mathrm{C}$ cases. The $[\mathrm{Sr}]-[\mathrm{Nd}]$ paths are distinct for these cases, and it is important to note that the continuous cases yield an initial increase in the average [Sr] in cumulates (Figure 12b). The $[\mathrm{Sr}]-{ }^{87} \mathrm{Sr} /{ }^{86} \mathrm{Sr}$ are distinct, and a noteworthy feature of Figure $12 b$ is that early in the cooling history of these magma bodies, [Sr] changes fairly dramatically without large changes in ${ }^{87} \mathrm{Sr} /{ }^{86} \mathrm{Sr}$. In contrast, once assimilation initiates, ${ }^{87} \mathrm{Sr} /{ }^{86} \mathrm{Sr}$ changes fairly dramatically, whereas [Sr] is buffered.

\section{Petrogenetic Processes Revealed Through Mass Relations}

[26] The sizes of plutonic bodies and volcanic eruptions on Earth vary by many orders of magnitude [e.g., Crisp, 1984]. Implicit in this range is information about processes in the associated magma network systems. Because EC-RAFC explicitly tracks the masses of standing melt, cumulates and enclaves, a link can be made between petrogenetic history, composition and volume for particular igneous products. For example, masses of enclaves versus cumulates versus melt for a particular RAFC event can be compared with natural data in order to match compositional signature with mass of product. Such a match would be powerful evidence of the utility of combining these types of data using EC-RAFC to understand magma chamber processes.

[27] Figure 13a illustrates the relationship between $\mathrm{T}_{\mathrm{m}}$ and $\mathrm{M}_{\mathrm{m}}$ (normalized mass of melt in standing magma body, see Spera and Bohrson, 2002 for explanation) for four continuous recharge cases. Parameters are the same as those in Table 1 with the following exceptions: CASE 1: $\mathrm{T}_{1, \mathrm{r}}=\mathrm{T}_{\mathrm{r}, \mathrm{o}}=$ $1400^{\circ} \mathrm{C}$; CASE 2: $\mathrm{T}_{1, \mathrm{r}}=\mathrm{T}_{\mathrm{r}, \mathrm{o}}=1250^{\circ} \mathrm{C}$; CASE 3: 

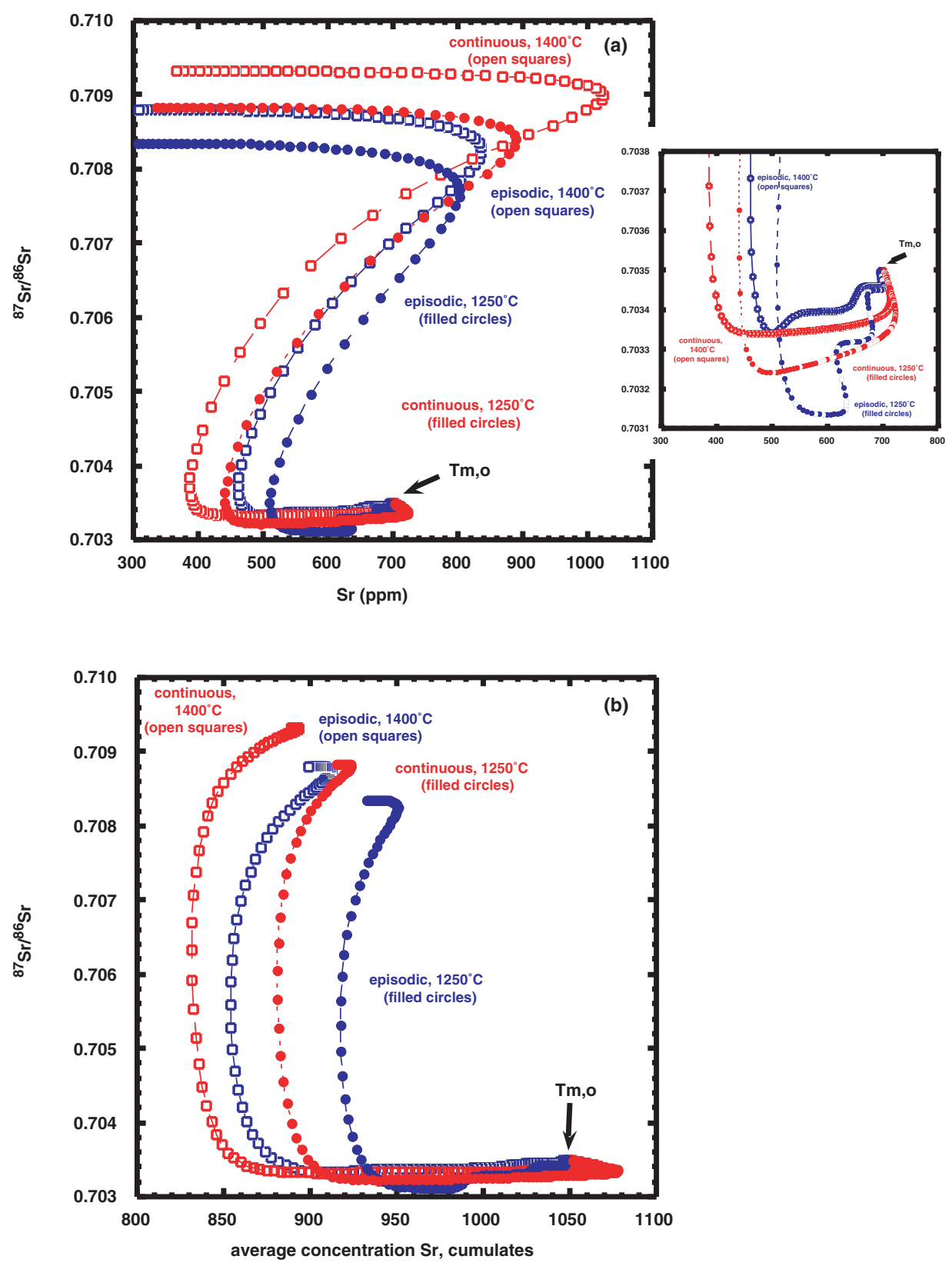

Figure 12. $\mathrm{Sr}(\mathrm{ppm})$ versus ${ }^{87} \mathrm{Sr} /{ }^{86} \mathrm{Sr}$ for (a) episodic and continuous recharge melts for RAFC cases where $\mathrm{T}_{1, \mathrm{r}}=$ $\mathrm{T}_{\mathrm{r}, \mathrm{o}}=1400^{\circ} \mathrm{C}$ and $\mathrm{T}_{1, \mathrm{r}}=\mathrm{T}_{\mathrm{r}, \mathrm{o}}=1250^{\circ} \mathrm{C}$. (inset) Expanded scale to show variations in $\mathrm{Sr}\left(\mathrm{ppm}\right.$ ) versus ${ }^{87} \mathrm{Sr} /{ }^{86} \mathrm{Sr}$ for four cases, (b) episodic and continuous recharge cumulates for same EC-RAFC cases.

$\mathrm{T}_{\mathrm{eq}}=1120^{\circ} \mathrm{C}$; CASE 4: $\mathrm{M}_{\mathrm{r}}=1$. None of the $\mathrm{T}_{\mathrm{m}}-\mathrm{M}_{\mathrm{m}}$ relationships is monotonic. Each curve increases from an initial value of 1 , reflecting the dominance of recharge at relatively high $\mathrm{T}_{\mathrm{m}}$. When fractional crystallization becomes significant, $\mathrm{M}_{\mathrm{m}}$ decreases in all cases. The increase of $\mathrm{M}_{\mathrm{m}}$ at relatively low $\mathrm{T}_{\mathrm{m}}$ reflects onset of assimilation, and thus for these cases, more mass is being added by assimilation and recharge than is being removed by fractional crystallization. Clearly, $\mathrm{T}_{\text {eq }}$ has a dramatic effect on $\mathrm{M}_{\mathrm{m}}$. For CASE 3, in which $\mathrm{T}_{\mathrm{eq}}=1120^{\circ} \mathrm{C}$, the magma body undergoes the least fractional crystallization, and therefore, at $\mathrm{T}_{\mathrm{eq}}, \mathrm{M}_{\mathrm{m}}$ is the largest. Consistent with this result, the masses of enclaves and cumulates are lowest (Figures 13b and 13c). Enclave formation is favored by high $\mathrm{M}_{\mathrm{r}}(\mathrm{CASE} 4)$ 

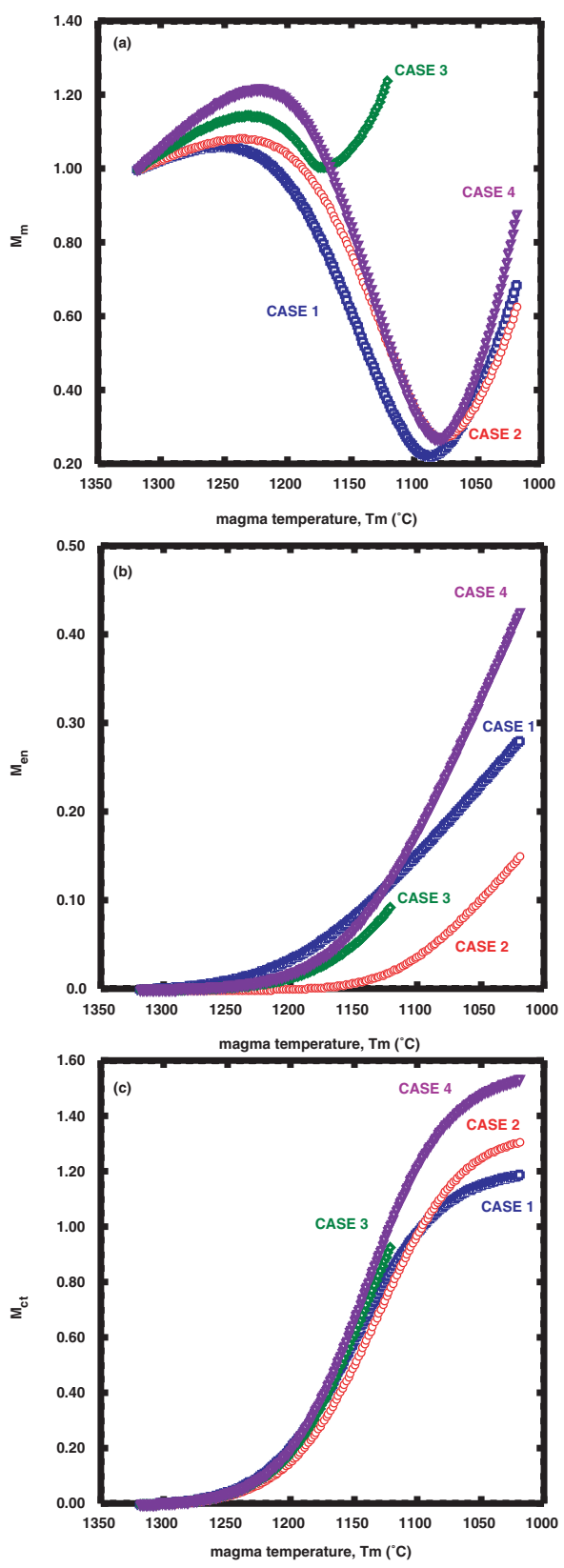

Figure 13. (a) $\mathrm{T}_{\mathrm{m}}\left({ }^{\circ} \mathrm{C}\right)$ versus $\mathrm{M}_{\mathrm{m}}$ (b) $\mathrm{T}_{\mathrm{m}}\left({ }^{\circ} \mathrm{C}\right)$ versus $\mathrm{M}_{\mathrm{en}}$ (c) $\mathrm{T}_{\mathrm{m}}\left({ }^{\circ} \mathrm{C}\right)$ versus $\mathrm{M}_{\mathrm{ct}}$ for CASES 1-4. CASE 1 shown by squares, CASE 2 by circles, CASE 3 by diamonds, and CASE 4 by inverted triangles.

and by $\mathrm{T}_{1, \mathrm{r}}\left(=\mathrm{T}_{\mathrm{r}, \mathrm{o}}\right)$ that is higher than $\mathrm{T}_{\mathrm{m}, \mathrm{o}}(\mathrm{CASE} 1)$. A common example would be injection of high $\mathrm{MgO}$-recharge melt into more evolved basaltic melt. Cumulate formation is favored by high $\mathrm{M}_{\mathrm{r}}$ (CASE 4) and $\mathrm{T}_{1, \mathrm{r}}\left(=\mathrm{T}_{\mathrm{r}, \mathrm{o}}\right)$ that is lower than $\mathrm{T}_{\mathrm{m}, \mathrm{o}}$ (CASE 2) because of obvious enthalpy considerations. Using this type of reasoning, relationships among masses of cumulates, enclaves, and melt estimated from field studies may shed light on the characteristics of an RAFC system.

[28] $\mathrm{M}_{\mathrm{r}} / \mathrm{M}_{\mathrm{ct}}$ (mass of recharge magma/mass of cumulates) is illustrated in Figure 14a. Like the analogous parameter $\mathrm{M}_{\mathrm{a}}^{*} / \mathrm{M}_{\mathrm{ct}}$ in EC-AFC [Bohrson and Spera, 2001], $\mathrm{M}_{\mathrm{r}} / \mathrm{M}_{\mathrm{ct}}$ is not generally constant as a magma body undergoes cooling and crystallization [c.f., DePaolo, 1985; Reagan et al., 1987]. For CASES 1-4 shown in Figure $14 \mathrm{a}, \mathrm{M}_{\mathrm{r}} / \mathrm{M}_{\mathrm{ct}}$ varies significantly $\left(\sim 23\right.$ to $<1$ from $\mathrm{T}_{\mathrm{m}}^{\mathrm{o}}$ to $\left.\mathrm{T}_{\mathrm{eq}}\right)$. The higher values at relatively high $\mathrm{T}_{\mathrm{m}}$ reflect input of recharge magma coupled with relatively small amounts of crystallization due to the nonlinear nature of the melt productivity functions. As noted in the geochemical results presented for these cases, it is fairly common for the higher $\mathrm{T}_{\mathrm{m}}$ stages of the RAFC event to be dominated by recharge, especially at shallower levels where crustal temperatures are relatively low and wallrock can absorb considerable heat before anatexis commences. As fractional crystallization becomes significant at lower $\mathrm{T}_{\mathrm{m}}, \mathrm{M}_{\mathrm{r}} / \mathrm{M}_{\mathrm{ct}}$ decreases dramatically.

[29] The ratios $M_{c t} / M_{m}$ and $M_{s} / M_{m}\left(M_{s}=M_{e n}+\right.$ $M_{c t}$ ) for the 4 cases shown in Figures $14 b$ and $14 c$ may also be useful in interpreting mass proportions of products from a magma chamber. These ratios vary from 0 to $\sim 1-5$ and 0 to $\sim 1-6$, respectively. Equilibration temperature has an important effect on these ratios. Compared to the other 3 cases, the $\mathrm{T}_{\mathrm{eq}}=$ $1120^{\circ} \mathrm{C}$ case (CASE 3 ) is melt-dominated throughout its cooling and crystallization history. In the other 3 cases, at higher $\mathrm{T}_{\mathrm{m}}$, the systems are meltdominated but become and stay solids-dominated at $\mathrm{T}_{\mathrm{m}}<1150-1130^{\circ} \mathrm{C}$. Thus, for $\sim 40 \%$ of the temperature range, these systems are solids-dominated and the probability of eruption is likely to be relatively low [Marsh, 1981]. $\mathrm{M}_{\mathrm{ct}} / \mathrm{M}_{\mathrm{m}}$ and $\mathrm{M}_{\mathrm{s}} / \mathrm{M}_{\mathrm{m}}>1$ attest to the potential importance solids have in the chemical composition of the crust, and quantifications such as these promise to shed light on the average composition of the crust as well as its compositional structure. The ability to quantify solid versus melt proportions should also yield information about the intrusive to extrusive ratio for a variety of magmatic systems. A possible application of this approach might include determining whether there are systematic differences in 

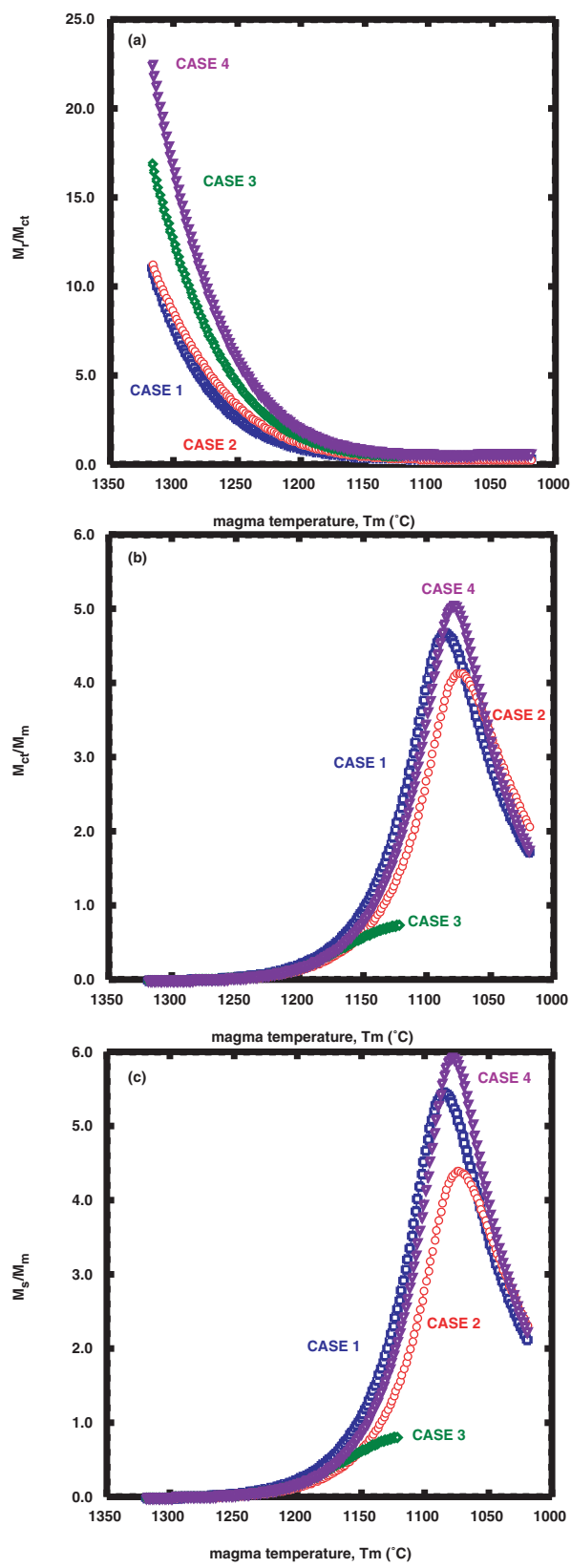

Figure 14. (a) $\mathrm{T}_{\mathrm{m}}\left({ }^{\circ} \mathrm{C}\right)$ versus $\mathrm{M}_{\mathrm{r}} / \mathrm{M}_{\mathrm{ct}}$ (b) $\mathrm{T}_{\mathrm{m}}\left({ }^{\circ} \mathrm{C}\right)$ versus $M_{c t} / M_{m}$ (c) $T_{m}\left({ }^{\circ} C\right)$ versus $M_{s} / M_{m}$ for CASES $1-4 .\left(M_{\mathrm{s}}=\mathrm{M}_{\mathrm{en}}+\mathrm{M}_{\mathrm{ct}}\right)$. Symbols for 4 CASES same as Figure 13.

cumulate, enclave, and melt masses among systems dominated by RAFC, AFC, RFC or FC or among igneous complexes located in different petrotectonic environments.

[30] Another potentially valuable application of the mass data provided by EC-RAFC involves their use to constrain magmatic systems where cumulates, enclaves and melts (preserved as volcanic rocks) are exposed. Such may be the case for some flood basalt-layered mafic intrusion complexes. Although in practice, application might be limited by exposure and degree of preservation, careful field studies may yield illuminating information about relationships among the masses of these sub-systems. The integration of field and geochemical data proposed here underscores some of the unique and novel capabilities of the EC-RAFC formulation.

[31] The ability to compare the geochemical and mass paths of an RAFC system potentially permits a more sophisticated understanding of the geochemical record preserved by volcanic and plutonic suites. For example, Figure 15 illustrates the ${ }^{87} \mathrm{Sr} /{ }^{86} \mathrm{Sr}-\mathrm{M}_{\mathrm{m}}$ relationships for CASES $1-4$. At higher $\mathrm{T}_{\mathrm{m}}$, there is a relatively large mass of melt characterized by a small range of ${ }^{87} \mathrm{Sr} /{ }^{86} \mathrm{Sr}$. Thus, if some small but constant volume of $\mathrm{M}_{\mathrm{m}}$ were to erupt at regular intervals as $T_{m}$ decreases, then the volcanic record would be characterized by a relatively homogenous $\mathrm{Sr}$ isotope signature. In contrast, once assimilation begins, if similar eruptive episodes were to occur, ${ }^{87} \mathrm{Sr} /{ }^{86} \mathrm{Sr}$ of the volcanic products would vary by several thousand ppm. At $\mathrm{T}_{\mathrm{m}}$ near $\mathrm{T}_{\mathrm{eq}}$, the melt erupted would be characterized by a homogeneous but more radiogenic $\mathrm{Sr}$ isotope signature than those preserved in highest $\mathrm{T}_{\mathrm{m}}$ phases of eruption. The coupling between the characteristics of the magma body and the erupted products can only be qualitatively described here because we have not yet explicitly incorporated eruption into EC-RAFC. However, general patterns can be inferred from the present formulation that may be useful in delineating the RAFC history of particular volcanic suites.

\section{The Occurrence of Chemically Homogeneous Magma Bodies}

[32] A review of the literature suggests that accounts of compositionally homogeneous eruptive phases (greater than a single eruption) are rare. Even in the cases where eruption is continuous for years (e.g., Jorullo, Arenal), the compositions of the volcanic rocks vary somewhat. For example, the 1759-1774 eruptions of Jorullo Vol- 


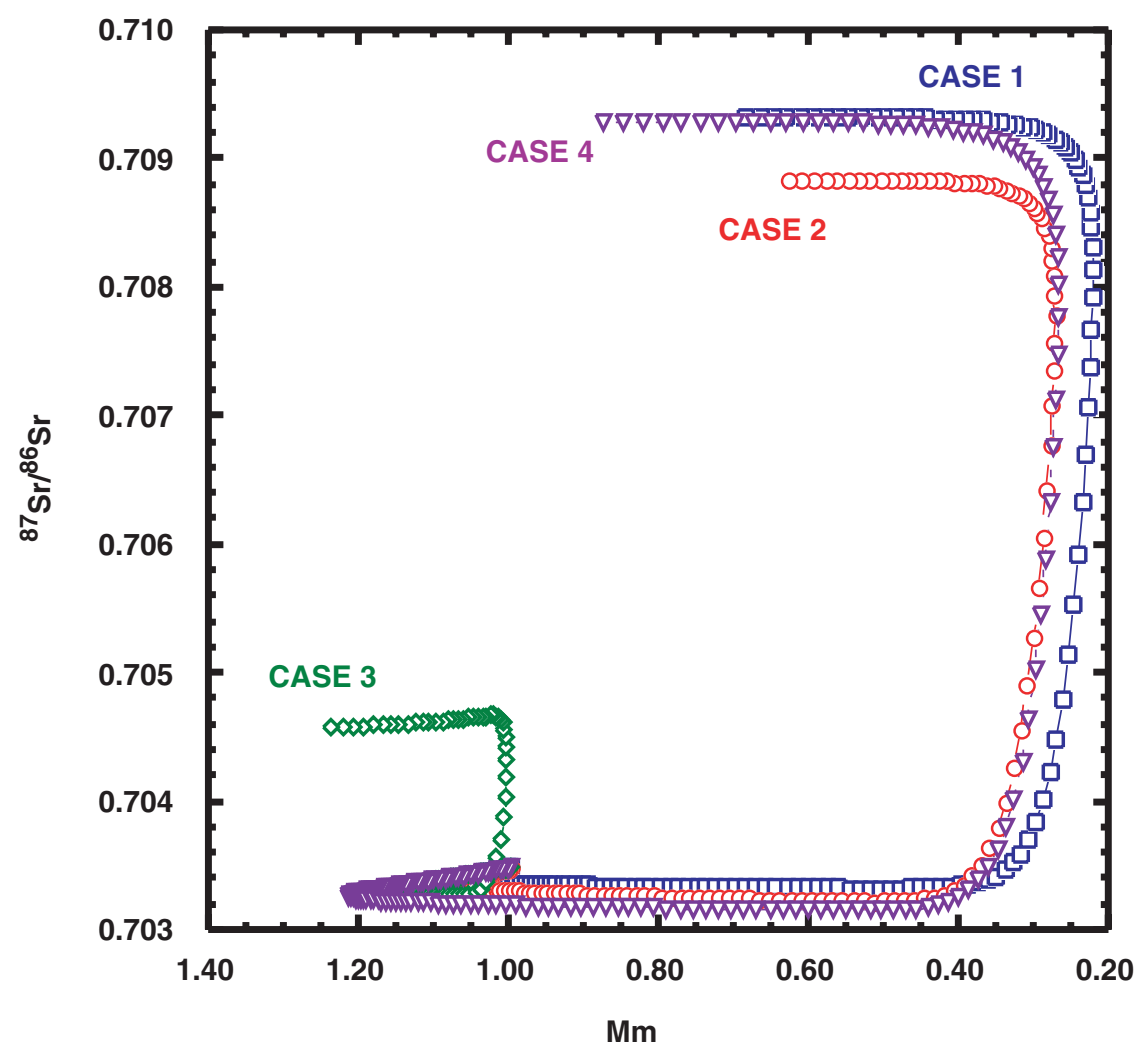

Figure 15. $\mathrm{M}_{\mathrm{m}}$ versus ${ }^{87} \mathrm{Sr} /{ }^{86} \mathrm{Sr}$ for CASES $1-4$. Symbols for 4 CASES same as Figure 13.

cano ranged from primitive basalt to basaltic andesite ( 52.1-54.7 wt.\% $\mathrm{SiO}_{2}, 9.3-4.3$ wt.\% $\mathrm{MgO}$; [Luhr and Carmichael, 1985]) and the 1968-1985 eruptions of Arenal were dominantly basaltic andesite to andesite ( 53.4-56.1 wt.\% $\mathrm{SiO}_{2}, 5.0-3.0$ wt.\% MgO [Reagan et al., 1987]). In contrast, lavas erupted at Paricutin between 1943 and 1946 , which represent $\sim 75 \%$ of the total eruption volume, were considered relatively homogeneous ( 54.6-56.1 wt.\% $\mathrm{SiO}_{2}, 5.6-5.4$ wt.\% $\mathrm{MgO}$ ) by McBirney et al. [1987]. The last 25\%, erupted between 1947 and 1952, was more varied in composition ( 57.1-60.2 wt.\% $\mathrm{SiO}_{2}, 5.6-3.6$ wt.\% MgO [McBirney et al., 1987]). Trace element variations in the early, more voluminous phase might also be considered relatively homogeneous, although $\mathrm{Sr}$ varied from 537 to $607 \mathrm{ppm}$ and $\mathrm{Ba}$ from 315 to $440 \mathrm{ppm}$. Such descriptions of the compositions of volcanic products, even in examples where the eruptions were continuous, underscore the problems associated with defining chemically homogeneous magma bodies (or parts of magma bodies). Over what timescale does the description apply, and how much latitude is permissible in describing an eruption or eruptive phase as chemically homogeneous?

[33] Table 3 summarizes EC-R(A)FC parameters for a case in which part of the magmatic history might be considered as characterized by magma that is compositionally homogeneous. By defining a high $\mathrm{T}_{1, \mathrm{a}}\left(2000^{\circ} \mathrm{C}\right)$, the simulation was designed to minimize assimilation because incorporation of anatectic melt tends to drastically change the composition of the magma body. It follows that an initial conclusion based on utilizing EC-RAFC is that typically, compositional homogeneity will be difficult to maintain once anatexis has begun. Figures 16 illustrates a range of approximately $140^{\circ} \mathrm{C}$ (of the total temperature range of $300^{\circ} \mathrm{C}$ from $\mathrm{T}_{\mathrm{m}}^{\mathrm{o}}$ to $\mathrm{T}_{\mathrm{eq}}$ ) which is characterized by $\mathrm{RFC}$ (where $\mathrm{R}$ is continuous) and where the concentrations of $\mathrm{Sr}, \mathrm{Nd}, \mathrm{Th}$, and $\mathrm{Ni}$ are within $10 \%$ of initial concentrations. A narrower compositional range would yield a smaller temperature range over which such compositional homogeneity would be 
Table 3. EC-R(A)FC Parameters for Continuous Recharge Case that Reflects Chemical Homogeneity

\begin{tabular}{|c|c|c|c|c|}
\hline \multicolumn{5}{|c|}{ Thermal Parameters $^{\mathrm{a}}$} \\
\hline $\begin{array}{l}\text { Pristine magma liquidus temperature, } \mathrm{T}_{1, \mathrm{~m}} \\
\text { Pristine magma initial temperature, } \mathrm{T}_{\mathrm{m}}^{\mathrm{o}} \\
\text { Recharge magma liquidus temperature, } \mathrm{T}_{1, \mathrm{r}} \\
\text { Recharge magma initial temperature, } \mathrm{T}_{\mathrm{r}}^{\mathrm{o}} \\
\text { Assimilant liquidus temperature, } \mathrm{T}_{1, \mathrm{a}} \\
\text { Assimilant initial temperature, } \mathrm{T}_{\mathrm{a}}^{\mathrm{o}} \\
\text { Total (normalized) mass of recharge magma } \\
\text { Solidus temperature, } \mathrm{T}_{\mathrm{s}} \\
\text { Equilibration temperature, } \mathrm{T}_{\mathrm{eq}}\end{array}$ & $\begin{array}{c}1320^{\circ} \mathrm{C} \\
1320^{\circ} \mathrm{C} \\
1320^{\circ} \mathrm{C} \\
1320^{\circ} \mathrm{C} \\
2000^{\circ} \mathrm{C} \\
200^{\circ} \mathrm{C} \\
0.5 \\
950^{\circ} \mathrm{C} \\
1020^{\circ} \mathrm{C}\end{array}$ & $\begin{array}{l}\text { crystallization enthalpy, } \\
\text { sobaric specific heat of } \\
\text { crystallization enthalpy, } \\
\text { sobaric specific heat of } \\
\text { fusion enthalpy, } \Delta \mathrm{h}_{\mathrm{a}}(\mathrm{J} / \mathrm{k} \\
\text { sobaric specific heat of }\end{array}$ & $\begin{array}{l}(\mathrm{J} / \mathrm{kgK}) \\
(\mathrm{J} / \mathrm{kgK}) \\
(\mathrm{J} / \mathrm{kgK}))\end{array}$ & $\begin{array}{c}396000 \\
1484 \\
396000 \\
1484 \\
354000 \\
1388\end{array}$ \\
\hline \multicolumn{5}{|c|}{ Compositional Parameters } \\
\hline & $\mathrm{Sr}$ & $\mathrm{Nd}$ & $\mathrm{Th}$ & $\mathrm{Ni}$ \\
\hline Pristine magma initial conc. $(\mathrm{ppm}), \mathrm{C}_{\mathrm{m}}^{\mathrm{o}}$ & 700 & 35 & 10 & 100 \\
\hline Pristine magma isotope ratio, $\varepsilon_{\mathrm{m}}^{\mathrm{o}}$ & 0.7035 & 0.5130 & - & - \\
\hline $\begin{array}{l}\text { Pristine magma trace element distribution } \\
\text { coefficient, } D_{m}\end{array}$ & 1.5 & 0.25 & 0.1 & 1.5 \\
\hline Recharge magma initial conc. (ppm), $\mathrm{C}_{\mathrm{r}}^{\mathrm{o}}$ & 1000 & 7 & 1 & 115 \\
\hline Recharge magma isotope ratio, $\varepsilon_{\mathrm{r}}^{\mathrm{o}}$ & 1.5 & 0.25 & - & - \\
\hline $\begin{array}{l}\text { Recharge magma trace element distribution } \\
\text { coefficient, } D_{r}\end{array}$ & 0.7028 & 0.5132 & 0.1 & 1.5 \\
\hline Assimilant initial conc. (ppm), $\mathrm{C}_{\mathrm{a}}^{\mathrm{o}}$ & 230 & 12.7 & 1.06 & 10 \\
\hline Assimilant isotope ratio, $\varepsilon_{\mathrm{a}}^{\mathrm{o}}$ & 0.7100 & 0.5122 & - & - \\
\hline $\begin{array}{l}\text { Assimilant trace element distribution } \\
\text { coefficient, } D_{a}\end{array}$ & 1.5 & 0.25 & 0.1 & 1.5 \\
\hline
\end{tabular}

${ }^{a}$ Non-linear parameterization of $f_{a}(T), f_{m}(T)$, and $f_{r}(T)$ used.

characterized. In order to achieve this result, the recharge magma compositional parameters in this simulation were iteratively modified. The results show a balance between addition of the element by recharge and variation due to fractional crystallization. $\mathrm{Sr}$ and $\mathrm{Ni}$ concentrations in the recharge magma are higher than those in the pristine magma because these elements are modeled as compatible in all sub-systems. In contrast, the concentrations of $\mathrm{Th}$ and $\mathrm{Nd}$ are lower in recharge magma than pristine magma because the elements are modeled as incompatible; this relationship allows the recharge magma to have a dilution effect on elements that would otherwise increase in concentration during fractional crystallization. Such concentrations would be consistent with recharge magma that is more mafic than pristine magma.

[34] Once assimilation becomes important, the concentrations of all of these elements vary substantially. The key point is that, based upon results using EC-RAFC, achieving compositional homogeneity is a challenging task because of the integrated effects of mass, species and energy conservation and the effects of partial melting, fractional crystallization and recharge. It is likely that the assumption of complete homogenization at each step in the EC-RAFC event maximizes the potential for compositional homogeneity in the theoretical magma body; the existence of compositionally zoned volcanic products suggests that this assumption is not always valid. Thus, an important prediction of the EC-RAFC formulation is that compositionally homogeneous magma bodies are likely to be relatively rare. This prediction is, in general, supported by data collected from natural systems.

\section{Conclusions}

[35] The Energy-Constrained Recharge, Assimilation, Fractional Crystallization (EC-RAFC) formulation tracks the mass, energy (enthalpy and temperature), trace element and isotopic composition of anatectic melt, magma body melt, cumulates generated by fractional crystallization and enclaves formed by chilling of recharge melt injected into an evolving magma body. The magma body, which represents one part of a three compo- 


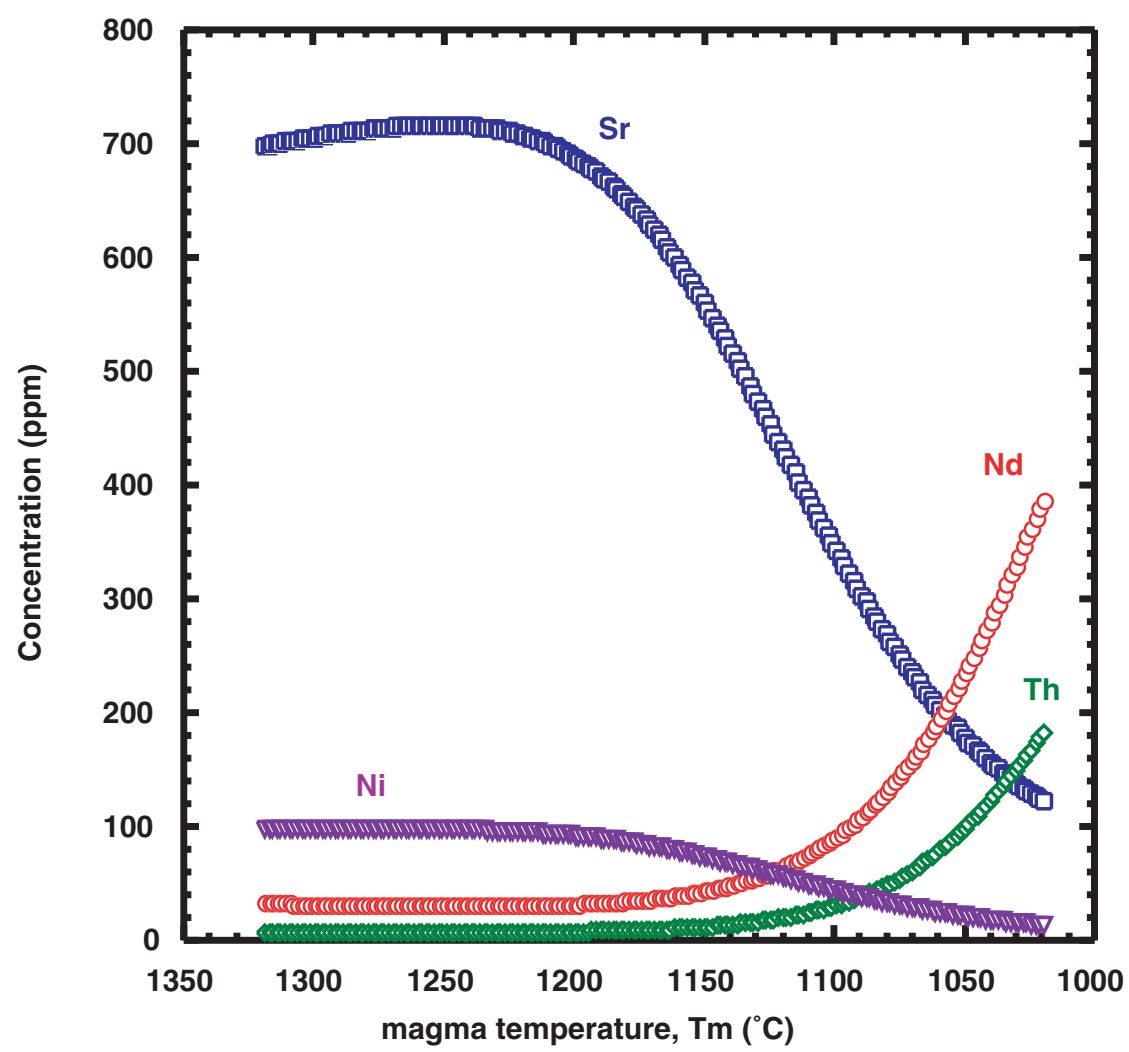

Figure 16. $\mathrm{T}_{\mathrm{m}}\left({ }^{\circ} \mathrm{C}\right)$ versus trace element (ppm) for melt of continuous recharge case presented in Table 3.

nent system amenable to thermodynamic characterization, undergoes simultaneous recharge, assimilation and fractional crystallization. Results of selected simulations clearly illustrate distinctions in composition that arise between systems characterized by episodic versus continuous recharge. Clear compositional differences in evolutionary trends in limiting cases (RFC or AFC) compared to the more general RAFC case are also apparent. Similarly, thermal conditions that favor formation of enclaves versus cumulates are easily explored. Injection of high specific enthalpy recharge melt into lower enthalpy standing melt results in enclave formation at the expense of cumulate formation. In contrast, injection of recharge magma of similar or less specific enthalpy results in a wave of cumulate formation with far less (or no) enclave formation. The quality of the correlations between the mass of added recharge melt $\left(\mathrm{M}_{\mathrm{r}}{ }^{\mathrm{o}}\right)$ and the extent of anatexis $\left(\mathrm{M}_{\mathrm{a}}{ }^{*}\right)$ depends on thermodynamic parameters and initial conditions. Based on EC-RAFC simulations, it appears that chemical homogeneity during cooling and crystallization of a magma body is favored when assimilation is negligible and when particular combinations of element concentrations and partition coefficients in recharge and pristine magma are maintained. These results are consistent with the small number of reported examples of phases of volcanic eruption or plutons that are chemically homogeneous. Because the composition and masses of melt and solids (cumulates and enclaves) are monitored by EC-RAFC, quantitative petrogenetic models describing the formation of any magmatic system can be investigated. Application of the formulation holds promise for increasing the understanding of magmatic systems as diverse as flood basalts, arc volcanoes, layered mafic intrusions, and granitic batholiths. The ability of EC-RAFC to predict mass and compositional relationships for individual magmatic systems also underscores the importance of well-constrained field-geochemical studies. For information about the availability of downloadable EC-RAFC code, go to http://mag- 
ma.geol.ucsb.edu/. A computer code for EC-AFC is available at the same website.

\section{Acknowledgments}

[36] We acknowledge the programming efforts of Guy Brown, who rendered our dense notations into functional code. We also thank Vincent Salters, an anonymous reviewer, guest editor Hubert Staudigel and editor Bill White for comments that helped improve the manuscript. Support for this project was provided by NSF EAR94-18720 (FJS), NSF EAR96-14381 (WAB). FJS acknowledges support from the U. S. Department of Energy DE-FG03-01ER-15210 and WAB acknowledges support from the Office of Graduate Studies and Research, Central Washington University.

\section{References}

Albaréde, F., Introduction to Geochemical Modeling, 543 pp., Cambridge Univ. Press, New York, 1995.

Bacon, C. R., and J. Metz, Magmatic inclusions in rhyolites, contaminated basalts, and compositional zonation beneath the Coso volcanic field, California, Contrib. Mineral. Petrol., 85, 346-365, 1984.

Benito, R., J. López-Ruiz, J. M. Cebriá, J. Hertogen, M. Doblas, R. Oyarzun, and D. Demaiffe, Sr and O isotope constraints on source and crustal contamination in the high-K calc-alkaline and shoshonitic neogene volcanic rocks of SE Spain, Lithos, 46, 773-802, 1999.

Bohrson, W. A., and F. J. Spera, Energy-constrained open-system magmatic processes II: Application of energy-constrained assimilation-fractional crystallization (EC-AFC) model to magmatic systems, J. Petrol., 42, 1019-1041, 2001.

Clemens-Knott, D., H. P. Taylor, and S. Sinigoi, Oxygen isotope evidence for massive interaction of basaltic magma with the deep continental crust: the mafic complex, Ivrea Zone, Italy, GSA Abstr. Programs, 31, 416, 1999.

Clynne, M. A., A complex magma mixing origin for rocks erupted in 1915, Lassen Peak, California, J. Petrol., 40, 105-132, 1999.

Crisp, J. A., Rates of magma emplacement and volcanic output, J. Volcanol. Geothermal Res., 20, 177-211, 1984.

Davidson, J. P., R. S. Harmon, and G. Wörner, The source of central Andean magmas; Some considerations, Geol. Soc. Am. Spec. Pap., 265, 233-243, 1991.

Decker, R. W., T. L. Wright, and P. H. Stauffer, The 19721984 Mauna Ulu eruption, Kilauea Volcano: An example of quasi-steady-state magma transfer, in Volcanism in Hawaii, edited by R. I. Tilling et al., U. S. Geol. Soc. Prof. Pap., 1350, 405-470, 1987.

DePaolo, D. J., Trace element and isotopic effects of combined wallrock assimilation and fractional crystallization, Earth Planet. Sci. Lett., 53, 189-202, 1981.

DePaolo, D. J., Isotopic studies of processes in mafic magma chambers, I, The Kiglapait Intrusion, Labrador, J. Petrol., 26, 925-951, 1985.
DePaolo, D. J., and G. J. Wasserburg, Petrogenetic mixing models and Nd-Sr isotopic patterns, Geochim. Cosmochim. Acta, 43, 615-627, 1979.

Dungan, M. A., and J. M. Rhodes, Residual glasses and melt inclusions in basalts from DSDP legs 45 and 46: Evidence for magma mixing, Contrib. Mineral. Petrol., 67, 417-431, 1978.

Eales, H. V., and R. G. Cawthorn, The Bushveld Complex, in Layered Intrusions, edited by R. G. Cawthorn, pp. 181-230, Elsevier Sci., New York, 1996.

Eichelberger, J. C., Vesiculation of mafic magma during replenishment of silicic magma reservoirs, Nature, 288, 446450, 1980.

Emeleus, C. H., The Rhum layered complex, Inner Hebrides, Scotland, in Origins of Igneous Layering, edited by I. Parsons, pp. 263-286, D. Reidel, Norwell, Mass., 1987.

Furman, T., and F. J. Spera, Co-mingling of acid and basic magma with implications for the origin of mafic i-type xenoliths: Field and petrochemical relations of an unusual dike complex at Eagle Lake, Sequoia National Park, California, U.S.A., J. Volcanol. Geothermal Res., 24, 151-178, 1985.

Gamble, J. A., C. P. Wood, R. C. Price, I. E. M. Smith, R. B. Stewart, and T. Waight, A fifty year perspective of magmatic evolution on Ruapehu Volcano, New Zealand: Verification of open system behaviour in an arc volcano, Earth Planet. Sci. Lett., 170, 301-314, 1999.

Gauthier, P. J., and M. Condomines, ${ }^{210} \mathrm{~Pb}^{226} \mathrm{Ra}$ radioactive disequilibria in recent lavas and radon degassing: Inferences on the magma chamber dynamics at Stromboli and Merapi volcanoes, Earth Planet. Sci. Lett., 172, 111-126, 1999.

Irvine, T. N., and C. H. Smith, The ultramafic rocks of the Muskox intrusion, Northwest Territories, Canada, in Ultramafic and Related Rocks, edited by P. J. Wyllie, pp. 38-49, John Wiley, New York, 1967.

James, D. E., The combined use of oxygen and radiogenic isotopes as indicators of crustal contamination, Annu. Rev. Earth Planet. Sci., 9, 311-344, 1981.

Leat, P. T., R. N. Thompson, M. A. Morrison, G. L. Hendry, and A. P. Dickin, Alkaline hybrid mafic magmas of the Yampa area, NW Colorado, and their relationship to the Yellowstone mantle plume and lithospheric mantle domains, Contrib. Mineral. Petrol., 107, 310-327, 1991.

Luhr, J. F., and I. S. E. Carmichael, Jorullo Volcano, Michoacan, Mexico (1759-1774): The earliest stages of fractionation in calc-alkaline magmas, Contrib. Mineral. Petrol., 90, 142-161, 1985.

Magaritz, M., D. J. Whitford, and D. E. James, Oxygen isotopes and the origin of high ${ }^{87} \mathrm{Sr} /{ }^{86} \mathrm{Sr}$ andesites, Earth Planet. Sci. Lett., 40, 220-230, 1978.

Marsh, B. D., On the crystallinity, probability of occurrence, and rheology of lava and magma, Contrib. Mineral. Petrol., 78, 85-98, 1981.

McBirney, A. R., H. P. Taylor, and R. L. Armstrong, Paricutin re-examined: A classic example of crustal assimilation in calc-alkaline magma, Contrib. Mineral. Petrol., 95, 4-20, 1987.

Miller, T. P., D. G. Chertkoff, J. C. Eichelberger, and M. L. Coombs, Mount Dutton Volcano, Alaska: Aleutian arc ana- 
log to Unzen Volcano, Japan, J. Volcanol. Geothermal Res., 89, 275-301, 1999.

Molzahn, M., L. Reisberg, and G. Worner, Os, Sr, Nd, Pb, O isotope and trace element data from the Ferrar flood basalts, Antarctica: Evidence for an enriched subcontinental lithospheric source, Earth Planet. Sci. Lett., 144, 529-546, 1996.

Montanini, A., M. Barbieri, and F. Castorina, The role of fractional crystallization, crustal melting and magma mixing in the petrogenesis of rhyolites and mafic inclusionbearing dacites from the Monte Arci volcanic complex (Sardinia, Italy), J. Volcanol. Geothermal Res., 61, 95120, 1994.

O'Hara, M. J., Geochemical evolution during fractional crystallisation of a periodically refilled magma chamber, Nature, 266, 503-507, 1977.

O'Hara, M. J., and R. E. Mathews, Geochemical evolution in an advancing, periodically replenished, periodically tapped, continuously fractionated magma chamber, Geol. Soc., 138, 237-277, 1981.

Reagan, M. K., J. B. Gill, E. Malavassi, and M. O. Garcia, Changes in magma composition at Arenal Volcano, Costa Rica, 1968-1985: Real-time monitoring of open system differentiation, Bull. Volcanol., 49, 415-434, 1987.

Rhodes, J. M., M. A. Dungan, D. P. Blanchard, and P. E. Long, Magma mixing at mid-ocean ridges: Evidence from basalts drilled near $22^{\circ} \mathrm{N}$ on the Mid-Atlantic Ridge, Tectonophysics, 55, 35-61, 1979.

Spera, F. J., and W. A. Bohrson, Energy-constrained open-system magmatic processes, I, General model and energy-constrained assimilation and fractional crystallization (EC-AFC) formulation, J. Petrol., 42, 999-1018, 2001.

Spera, F. J., and W. A. Bohrson, Energy-constrained opensystem magmatic processes III: Energy-constrained recharge, assimilation, and fractional crystallization, Geochem. Geophys. Geosyst, doi:10.1029/2002GC000315, in press, 2002.

Takada, A., Variations in magma supply and magma partitioning: The role of tectonic settings, J. Volcanol. Geothermal Res., 93, 93-110, 1999.
Taylor, H. P., The effects of assimilation of country rocks by magmas on ${ }^{18} \mathrm{O} /{ }^{16} \mathrm{O}$ and ${ }^{87} \mathrm{Sr} /{ }^{86} \mathrm{Sr}$ systematics in igneous rocks, Earth Planet. Sci. Lett., 47, 243-254, 1980.

Taylor, S. R., and S. M. McLennan, The Continental Crust: Its Composition and Evolution: An Examination of the Geochemical Record Preserved in Sedimentary Rocks, 307 pp., Blackwell Sci., Malden, Mass., 1985.

Tepley, F. J., J. P. Davidson, R. I. Tilling, and J. G. Arth, Magma mixing, recharge and eruption histories recorded in plagioclase phenocrysts from El Chichon Volcano, Mexico, J. Petrol., 41, 1397-1411, 2000.

Tilling, R. I., R. L. Christiansen, W. A. Duffield, E. T. Endo, R. T. Holcomb, R. Y. Koyanagi, D. W. Peterson, and J. D. Unger, The 1972-1974 Mauna Ulu eruption, Kilauea Volcano: An example of quasi-steady-state magma transfer, in Volcanism in Hawaii, edited by R. W. Decker, T. L. Wright, and P. H. Stauffer, U. S. Geol. Surv. Prof. Pap., 1350, 1987.

Umino, S., and A. Horio, Multistage magma mixing revealed in phenocryst zoning of the Yunokuchi pumice, Akagi Volcano, Japan, J. Petrol., 39, 101-124, 1998.

Volker, J. A., and B. G. J. Upton, The structure and petrogenesis of the Trallval and Ruinsival areas of the Rhum ultrabasic complex, Trans. R. Soc. Edinburgh Earth Sci., 81, 6988, 1990.

Vroon, P. Z., M. J. V. Bergen, W. M. White, and J. C. Varekamp, Sr-Nd-Pb isotope systematics of the Banda Arc, Indonesia: Combined subduction and assimilation of continental material, J. Geophys. Res., 98, 22,349-22,366, 1993.

Wadge, G., Steady state volcanism: Evidence from eruption histories of polygenetic volcanoes, J. Geophys. Res., 87, 4035-4049, 1982.

Waight, T. E., R. Maas, and I. A. Nicholls, Geochemical investigation of microgranitoid enclaves in the S-type Cowra Granodiorite, Lachlan Fold Belt, SE Australia, Lithos, 56, 165-186, 2001.

Wiebe, R. A., H. Frey, and D. P. Hawkins, Basaltic pillow mounds in the Vinalhaven intrusion, Maine, J. Volcanol. Geothermal Res., 107, 171-184, 2001.

Wilcox, R. E., Petrology of Paricutin Volcano, Mexico, U. S. Geol. Surv. Bull., 965-C, 1954. 